\title{
Akar Pluralisme dalam Pendidikan Muhammadiyah
}

DOI 10.18196/AIIJIS.2016.0053.1-42

\section{ABDUL MU'TI}

Universitas Islam Negeri (UIN) Syarif Hidayatullah, Jakarta

Email: abe_mukti@yahoo.com

\section{ABSTRACT}

This paper discusses the nature of Muhammadiyah educational institutions and relates it to the diverse socio-religious background of Indonesian society. Renowned as the largest modernist Islamic movement in Indonesia and Southeast Asia, which promotes the purity of Islam, Muhammadiyah in fact has been faced with notions of religious and cultural pluralism, and therefore, it has to seeks ways of how to formulate Islam in plural society. This article is a theoretical exposition of Muhammadiyah and its encounters with religious pluralism, and how Muhammadiyah translates notions of pluralism into praxis in its educational institutions. This paper argues that educational institutions of Muhammadiyah have widened path for deepening inter-religious dialogue and interaction in the diversity of Indoensian society.

Keywords: religious pluralism, education, da'wa, ideology, Muhammadiyah

\section{ABSTRAK}

Artikel ini mengkaji karakteristik lembaga pendidikan Muhammadiyah dan mengaitkannya dengan keragaman latarbelakang sosial-keagamaan masyarakat Indonesia. Dikenal sebagai gerakan Islam modernis di Indoensia dan di Asia Tenggara, yang mempromosikan kemurnian ajaran islam, Muhammadiyah nampaknya harus berhadapajn dengan keanekaragaman agama dan budaya dan untuk itu, Muhammadiyah mencoba mencari jalan bagaimana menerjemahkan islam dalam masyarakat plural. Tulisan ini merupakan kajian teoretis tentang Muhammadiyah dan interaksinya dengan masalah pluralisme agama, serta bagaimana Muhammadiyah menerjemahkan gagasan pluralisme agama ke dalam praksis di bidnag pendidikan. Artikel ini berpendapat bahwa lembaga pendidikan Muhammadiyah telah membuka jalan yang luas untuk hubungan dan dialog antar agama.

Kata kunci: pluralisme agama,pendidikan, dakwah, ideologi, Muhammadiyah 


\section{PENDAHULUAN}

Indonesia adalah negeri yang multikultural dan multireligius. Selama berabad-abad bangsa Indonesia yang terdiri atas beratus-ratus suku dan etnis ${ }^{1}$ serta memeluk agama dan keyakinan yang berbeda-beda ${ }^{2}$ hidup berdampingan secara damai. Bangsa Indonesia sangat religius dan taat menjalankan ajaran agamanya ${ }^{3}$ tetapi, Indonesia bukanlah negara agama (non-theocratic state). Negara Indonesia berdasarkan atas Pancasila yang digali dari nilai-nilai tradisional bangsa Indonesia. Pancasila-meminjam istilah Abdullah An-Naim-adalah "Golden Rule" (Kaidah Dasar) yang memiliki nilai-nilai universal lintas kebudayaan, agama dan hak asasi manusia. ${ }^{4}$ Eksistensi Pancasila diterima oleh mayoritas umat beragama ${ }^{5}$ karena memayungi pluralitas dan kemerdekaan setiap warga negara untuk menjalankan ibadah sesuai dengan keyakinannya. ${ }^{6}$

Melalui proses akomodasi, akulturasi dan asimilasi yang alamiah pluralitas agama dan budaya membentuk karakter bangsa yang toleran dan terbuka. Mayoritas penduduk Indonesia beragama Islam, tetapi "trade mark" kebudayaannya adalah warisan Hindu dan Buddha seperti Candi Borobudur dan Prambanan, dll. Kuatnya pertautan antara agama dan kebudayaan membuat agama-agama di Indonesia- termasuk Islam-cenderung sinkretis.? Secara sosiologis, sinkretisme tidak selalu bermakna negatif. Pesantren sebagai lembaga pendidikan yang khas Indonesia adalah produk sinkretisme IslamJawa. Pengaruh Jawa dalam Islam juga terlihat dalam perayaan keagamaan, arsitektur masjid, dll. ${ }^{8}$

Pluralitas agama sebagai koeksistensi sosiologis yang damai telah menjadi tradisi bangsa Indonesia. Dalam bidang pendidikan, banyak siswa Muslim yang belajar di sekolah-sekolah non-Muslim atau sebaliknya. Pernikahan beda agama sekarang semakin lazim terjadi. Bahkan, dalam suku-suku tertentu ikatan kekerabatan dalam bentuk marga atau yang lainnya lebih kuat dibanding agama.

Meskipun terdapat gejala meningkatnya kelompok Salafi Radikal, mainstream Muslim Indonesia adalah kelompok moderat. ${ }^{9}$ Islam moderat memiliki empat karakteristik. Pertama, menerima demokrasi ala Barat sebagai alat untuk memilih pemimpin dan wakil rakyat. Kedua, menerima hukum negara yang nonsektarian dalam pengertian tidak mendukung penerapan Syariat Islam dalam hukum atau politik pemerintahan. Ketiga, menghormati hak-hak perempuan dan kaum minoritas agama. Mereka bersikap hospitable terhapat kaum Feminis dan terbuka terhadap pluralisme dan dialog antaragama. Keempat, menentang terorisme dan tidak kekerasan yang melanggar hukum. ${ }^{10}$ 
Sayangnya, karakter kebudayaan dan keberagamaan bangsa Indonesia yang toleran tampaknya mulai luruh. Dalam satu dasawarsa terakhir paska reformasi politik, serangkaian aksi anarkis dan konflik komunal bernuansa SARA (Suku, Agama, Ras, Antar-Golongan) meledak di beberapa kawasan di Indonesia. Ribuan orang meninggal dalam serangkaian tindak kekerasan bernuansa SARA yang terjadi Maluku, Poso (Sulawesi Tengah) dan Kalimantan Barat. Di Jawa Timur, Nusa Tenggara Barat, Jawa Barat dan beberapa tempat lainnya ratusan rumah ibadah luluh lantak oleh amukan massa. Pengikut aliran agama tertentu yang dianggap "sesat" masih hidup dalam keterasingan dan ketakutan. Mengapa demikian?

Banyak faktor yang mempengaruhi kekerasan keagamaan. Beberapa studi menjelaskan kekerasan keagamaan yang terjadi di berbagai belahan dunia lebih banyak disebabkan oleh faktor eksternal non-agama. Menurut Vanessa Baird, politik merupakan faktor yang paling dominan. ${ }^{11}$ Di Indonesia, kekerasan keagamaan disebabkan oleh politisasi agama untuk kepentingan kekuasaan, khususnya mereka yang pro status quo. ${ }^{12}$ Pelaksanaan demokrasi liberal menjadi momentum kebangkitan politik identitas yang ditandai oleh menjamurnya partai berbasis agama. Otonomi Daerah juga membawa ekses meningkat sentimen primordialisme etnis. Isu "putera daerah" adalah komoditas politik yang hampir selalu muncul dalam setiap Pemilihan Kepada Daerah. Kekerasan keagamaan acapkali terjadi dalam proses transisi demokrasi, otonomi pemerintahan dan akomodasi identitas politik. ${ }^{13}$

Dalam beberapa kasus, kekerasan keagamaan juga disebabkan oleh faktor ekonomi. Konflik Ambon, misalnya, sarat dengan persaingan perebutan kekuasaan dan aset ekonomi antar kelompok yang akar-akarnya sudah tumbuh sejak masa kolonialisme Belanda. ${ }^{14}$ Faktor kesenjangan ekonomi juga menjadi pemicu kekerasan antara "penduduk asli" dengan "pendatang" di beberapa daerah transmigrasi. Kekerasan rasial di Kalimantan Barat nampaknya tidak terlepas dari persaingan ekonomi antara suku Dayak versus Madura.

Faktor lain yang mempengaruhi kekerasan keagamaan adalah globalisasi. ${ }^{15}$ Dalam perkembangannya, globalisasi yang disertai oleh mengalirnya arus kapital, barang dan informasi dari negara-negara maju ke negara-negara berkembang menimbulkan masalah neokolonialisme: ekonomi dan kultural. Kesenjangan ekonomi Utara-Selatan yang semakin lebar, dominasi budaya Baru (baca: Barat) menggerus nilai-nilai tradisional-termasuk agama. ${ }^{16}$ Situasi demikian menyuburkan perkembangan radikalisme atau fundamentalisme agama sebagai upaya perlawanan untuk melindungi identitas tradisi dan 
"kedaulatan" politik. ${ }^{17}$ Kekerasan keagamaan di Indonesia dipicu oleh isu-isu politik global dan kesalahpahaman budaya (cultural misunderstanding).

Faktor internal yang bermuara pada pemahaman agama juga bisa menjadi salah satu penyebab kekerasan keagamaan. Menurut Charles Kimball, jika dimaknai secara inklusif, agama mampu memersatukan umat manusia. Sebaliknya, pemahaman agama yang sempit dan eksklusif bisa menimbulkan masalah. "Keyakinan arogan terhadap agama seseorang dibarengi dengan penolakan yang menyakitkan atas agama lain sesungguhnya malah memperkuat argumen bahwa agama memang merupakan satu masalah". ${ }^{18}$ Dalam konteks Islam, jika dipahami secara literal skripturalistik konsep mulia seperti jihad dapat menjadi dalih untuk bersikap agresif, melakukan tindak kekerasan kepada pihak lain bahkan terorisme. ${ }^{19}$

Pendidikan agama merupakan faktor penting yang mempengaruhi pemahaman agama. Sebagian kalangan berpendapat, terjadinya kekerasan keagamaan di Indonesia akhir-akhir ini disebabkan oleh kegagalan pendidikan agama. Pendidikan agama yang terlalu menekankan domain kognitif dengan pendekatan pembelajaran yang doktriner cenderung membentuk pemahaman agama yang sempit dan eksklusif. ${ }^{20 " S e b a g i a n ~ b e s a r ~ y a n g ~ d i h a s i l k a n ~ d a r i ~}$ pendidikan agama selama ini mungkin hanya orang-orang memiliki pemikiran yang terpecah dalam beragama... orang-orang yang mencintai agamanya sendiri... yang mudah dipicu kebenciannya terhadap agama lain. "21

Apakah pendidikan agama benar-benar gagal? Dengan segala kekurangannya, pendidikan agama berperan penting dalam membangun religiusitas dan moralitas bangsa. Bahkan, menurut Kuntowijoyo, formalisasi pendidikan agama di sekolah merupakan faktor penting yang mempengaruhi terjadinya konvergensi sosial dan Islam di Indonesia yaitu konvergensi sosial antara wong cilik dengan priyayi, konvergensi budaya antara abangan dan santri serta konvergensi aliran antara tradisionalis, modernis dan puritan. Kewajiban mengikuti pendidikan agama di sekolah, memungkinkan siswa dari berbagai latar belakang sosial mempelajari agama melalui guru agama dan sumber belajar yang sama. ${ }^{22}$ Karena itu, pokok masalahnya bukan pada substansi agama dan pendidikan agama melainkan pada aspek metodologi pemahaman dan pendidikan agama. Permasalahannya terletak pada sistem pendidikan agama.

Bagaimana sistem pendidikan agama dalam masyarakat multireligius? Dalam praktiknya, terdapat tiga aliran pendidikan agama. Pertama, pendidikan agama tidak perlu diajarkan sebagai studi wajib dalam kurikulum sekolah 
tetapi cukup diberikan di dalam keluarga dan masyarakat melalui lembagalembaga keagamaan. ${ }^{23}$ Kedua, pendidikan agama diajarkan di sekolah dalam kedudukannya sebagai ilmu sosial (social science) yang bersifat non-confessional. Sistem pendidikan agama bertujuan semata-mata untuk mempelajari agama sebagai ilmu dan pengetahuan tentang masyarakat (learning to know about religion), bukan untuk menanamkan keyakinan dan membentuk manusia taat kepada agamanya (learning to be religious persons). Ketiga, pendidikan agama diajarkan di sekolah sebagai studi wajib yang bersifat confessional. Sistem pendidikan agama bertujuan untuk menanamkan dan memperteguh keyakinan terhadap agama untuk memperkuat identitas bangsa. ${ }^{24}$

Pemerintah Indonesia mengembangkan sistem pendidikan agama confessional. Secara historis, sistem pendidikan agama confessional bukanlah sistem yang baru karena pernah diberlakukan pada masa penjajahan Portugis dan Belanda. Pada masa pemerintahan Presiden Soekarno, pendidikan agama confessional bersifat pilihan, bukan merupakan studi wajib bagi setiap siswa. Pada pemerintahan Orde Baru melakukan formalisasi dan institusionalisasi pendidikan agama sebagai studi wajib yang diajarkan kepada seluruh siswa di semua jenjang pendidikan. ${ }^{25}$ Pengembangan sistem pendidikan agama confessional didasarkan atas tiga alasan. Pertama, alasan konstitusional yang mengacu kepada sila pertama Pancasila-Ketuhanan Yang Maha Esa-dan pasal 29 (1) Undang-undang Dasar 1945: "Negara berdasarkan atas Ketuhanan Yang Maha Esa". Kedua, alasan sosiologis untuk memelihara karakteriktik bangsa Indonesia yang religius. Ketiga, alasan politis agama sebagai hak asasi manusia dan pengalaman politik Indonesia dengan komunisme. Sistem pendidikan agama confessional ditegaskan dalam Undang-undang nomor 2/ 1989 tentang Pendidikan Nasional juncto Undang-undang nomor 20/2003 tentang Pendidikan Nasional terutama pada rumusan tujuan pendidikan nasional, ${ }^{26}$ pengembangan dan muatan kurikulum ${ }^{27}$ dan hak peserta didik. ${ }^{28}$ Selain itu, pemerintah Indonesia juga mengeluarkan Peraturan Pemerintah nomor 55/2007 tentang pelaksanaan pendidikan agama dan pendidikan keagamaan.

Dalam praktiknya, peraturan perundangan tentang pendidikan agama yang sudah tidak terlaksana sebagaimana mestinya. Ada dua alasan utama mengapa pendidikan agama tidak dilaksanakan sesuai ketentuan perundang-undangan. Pertama, keterbatasan tenaga pendidik (guru). Karena sekolah tidak memiliki guru agama maka pendidikan agama diajarkan oleh guru bidang studi lain 
yang dinilai memiliki kompetensi pengetahuan agama. Kedua, alasan ideologis. Sekolah mengembangkan sistem pendidikan agama tersendiri karena lebih mengutamakan "misi" agama sebagaimana dikembangkan oleh Muhammadiyah, Ahmadiyah, Kristen, dan Katolik.

Secara umum terdapat tiga model sistem pendidikan agama di sekolahsekolah agama. Pertama, model "eksklusif" di mana siswa yang berbedabeda agama hanya menerima satu pendidikan agama confessiona/yang sesuai dengan agama sekolah yang diajarkan oleh guru agama. Sebagai contoh, tanpa memperhatikan agamanya seluruh siswa yang belajar di sekolah Kristen wajib mengikuti pendidikan agama Kristen yang diajarkan oleh guru Kristen. Kedua, model "inklusif" di mana siswa yang berbeda-beda agama mempelajari ajaran beberapa agama. Dalam model ini pendidikan agama bersifat nonconfessional yang menekankan aspek kognitif: siswa memahami dan membandingkan ajaran beberapa agama, menemukan nilai-nilai persamaan antaragama. Selama proses pembelajaran siswa dipandu oleh seorang guru agama yang berperan sebagai fasilitator. Model "pendidikan religiusitas" ini dikembangkan sebagai "strategi" untuk meningkatkan pemahaman dan kesadaran siswa tentang pluralitas agama dalam masyarakat. ${ }^{29}$ Ketiga, model "pluralis" dimana siswa mendapatkan dua "pendidikan agama". Yang pertama, siswa menerima pendidikan agama confessiona/ sebagaimana diatur di dalam perundang-undangan pendidikan. Selain itu, siswa wajib mengikuti "pendidikan keagamaan" non-confessional sesuai dengan agama sekolah.

Perbedaan model sistem pendidikan agama di sekolah-sekolah agama disebabkan oleh perbedaan "ijtihad" dalam menyinergikan ketentuan undangundang, misi agama dan konteks sosial-budaya masyarakat. Pertama, sekolah sebagai lembaga publik terikat oleh hukum dan perundang-undangan. Sekolah tidak hanya terikat oleh undang-undang pendidikan nasional, tetapi juga undang-undang tentang perlindungan anak, peraturan pemerintah tentang penyebaran agama dan perundang-undangan lainnya. Kedua, sekolah sebagai lembaga agama didirikan sebagai agen penyebaran agama (an agent of religious missionary). Ketiga, sekolah sebagai lembaga sosial terikat oleh konteks sosial-budaya dan agama masyarakat. Sebagai lembaga sosial berperan untuk memelihara kerukunan sosial dan memberikan pelayanan kepada sesama.

Idealnya, sekolah agama dapat mengintegrasikan tiga fungsi sekolah sebagai lembaga pendidikan, dakwah dan sosial. Tetapi, sekolah agama kadangkala berada dalam posisi yang dilematis: antara mematuhi undang-undang dengan pengembangan dakwah agama. Jika sekolah lebih mengutamakan pelaksanaan 
undang-undang, maka peranannya sebagai lembaga misi tidak maksimal. Jika sekolah lebih mengutamakan misi, maka ada kecenderungan sekolah melanggar undang-undang. Pilihan-pilihan prioritas inilah yang menyebabkan pendidikan agama di sekolah agama bisa menjadi sumber konflik dan ketegangan antarumat beragama. ${ }^{30}$

Bagaimana sekolah agama mengembangkan model sistem pendidikan yang menyinergikan kewajiban yuridis-politis, mengembangkan misi agama dan memelihara pluralitas keagamaan merupakan kajian yang menarik. Dengan jumlah sekolah yang sangat besar dan latar belakang keagamaan siswa yang beragam, ${ }^{31}$ Muhammadiyah juga harus berhadapan dengan situasi yang dilematis tersebut. Bagaimana sekolah-sekolah Muhammadiyah mengembangkan model sistem pendidikan agama dan dampak sosial model pendidikan yang dikembangkannya merupakan masalah yang memerlukan studi mendalam.

Muhammadiyah adalah gerakan Islam dan dakwah amar ma'ruf nahi munkar yang bertujuan untuk membangun masyarakat Islam yang sebenarbenarnya. Latar belakang kelahiran Muhammadiyah erat kaitannya dengan berbagai problem sosial dan keagamaan yang disebabkan oleh kehidupan agama yang sinkretis menyimpang dari ajaran al-Qur'an dan Hadits, kemunduran pendidikan Islam dan keterbelakangan umat Muslim, agresivitas kegiatan misionaris Kristen/Katolik dan penetrasi bangsa-bangsa Eropa. ${ }^{32}$

Sejak berdiri pada tahun 1912, Muhammadiyah menyelenggarakan pendidikan yang terbuka untuk semua (education for all). Lembaga pendidikan Muhammadiyah menerima siswa tanpa memandang latar belakang agama, etnis, kewarganegaraan dan ekonomi (non-discriminative). Sekolah sebagai amal usaha Muhammadiyah memiliki tiga fungsi: pendidikan, dakwah Islam amar ma'ruf nahi munkar dan perkaderan. Hal tersebut nampak dalam visi dan misi Majelis Pendidikan Dasar Menengah (Dikdasmen) sebagai majelis yang secara khusus berkhidmat dalam penyelenggaraan pendidikan Muhammadiyah. Visi Majelis Dikdasmen adalah tertatanya manajemen dan jaringan pendidikan yang efektif sebagai gerakan Islam yang maju, profesional dan modern serta untuk meletakkan landasan yang kokoh bagi peningkatan kualitas pendidikan Muhammadiyah. Adapun misi majelis Dikdasmen adalah: (a) menegakkan keyakinan Tauhid yang murni; (b) menyebarluaskan ajaran Islam yang bersumber kepada al-Qur'an dan Sunnah. (c) mewujudkan amal Islami dalam kehidupan pribadi, keluarga dan masyarakat; (d) menjadikan lembaga pendidikan Muhammadiyah sebagai pusat pendidikan, dakwah dan 
perkaderan. $^{33}$

Sesuai dengan konteks tersebut, artikel ini berusaha mengkaji tiga permasalahan pokok tentang akar-akar pluralisme dalam pendidikan Muhammadiyah. Permasalahan ini terkait dengan tiga pertanyaan: (a) ideologi Muhammadiyah sebagai gerakan Islam dan dakwah amar ma'ruf nahi munkar; (b) konsep atau pemahaman Muhammadiyah tentang pluralisme agama; (c) implementasi dakwah dan pluralisme dalam pendidikan.

\section{KAJIAN TENTANG ISLAM DAN PLURALISIME AGAMA}

Kajian tentang pluralisme agama dan multikulturalisme mulai mendapatkan perhatian semenjak reformasi politik yang ditandai oleh perkembangan demokrasi yang cenderung liberal, otonomi daerah, good governance, keterbukaan politik dan merebaknya kekerasan bernuansa etnis dan agama. Meskipun gagasan tentang pluralisme, demokrasi, civil society dan multikulturalisme cukup banyak ditulis dan diterbitkan, penelitian tentang pluralisme dalam pendidikan masih sangat terbatas, khususnya yang terkait dengan Muhammadiyah.

Penelitian tentang pluralisme dalam pendidikan dapat diklasifikasikan menjadi dua jenis. Pertama, penelitian yang terkait dengan kebijakan politik dan perundang-undangan pendidikan sebagai hard-pluralism. Dua penelitian penting mengenai hal ini dilakukan oleh M. Saerozi ${ }^{34}$ dan Abdurrahman Assegaf. ${ }^{35}$ Saerozi dan Assegaf melakukan kajian historis tentang kebijaksanaan pendidikan agama sejak masa kolonialisme Belanda dan Portugis sampai era reformasi. Dalam penelitiannya, Saerozi menemukan bahwa meskipun pola kebijakannya berbeda-beda, pemerintah Belanda, Portugis dan Indonesia samasama mengembangkan pola pendidikan agama konfesional dimana negara memberikan legitimasi pendidikan agama untuk meningkatkan keimanan dan ketaatan siswa terhadap ajaran agamanya. Jika pemerintah VOC dan Portugis menerapkan kebijaksanaan dominasi terhadap Kelompok Keyakinan Minoritas (KKM), pemerintah Hindia Belanda memberlakukan pola penelantaran terhadap KKM. Pemerintah Indonesia berupaya mengembangkan kebijakan pendidikan agama konfesional yang lebih ideal, tetapi "warisan" kolonial yang berpola mendominasi atau menelantarkan KKM tidak bisa dihindari. Karena itu, menurut Saerozi, Indonesia memerlukan kebijaksanaan pendidikan agama yang bersumber dari konsep "pluralisme agama konfesional" yang memberdayakan KKM sehingga negara bisa membebaskan diri dari pola dominasi maupun penelantaran. 
Senada dengan Saerozi, penelitian Assegaf menjelaskan bagaimana perubahan kebijakan atau politik pendidikan agama di Indonesia banyak dipengaruhi oleh kepentingan politik pemerintah, konteks dan dinamika politik nasional dan kontestasi kepentingan dari berbagai kelompok, termasuk di dalamnya umat beragama. Masalah pluralisme agama selalu menyertai hampir semua perdebatan tentang pendidikan agama khususnya di sekolah. Menurut Assegaf, dalam era demokrasi yang meniscayakan keterbukaan dan kebebasan, meningkatnya kesadaran tentang hak asasi manusia dan identitas merupakan kondisi yang mengharuskan kebijakan pendidikan agama yang propluralisme.

Apakah kebijakan pendidikan agama yang pluralistik mampu membentuk sikap positif terhadap pluralisme? Beberapa penelitian tentang model atau pola pendidikan agama menunjukkan bahwa sikap pluralisme dapat dibentuk melalui pendidikan. Penelitian Ruswan, Listia, Yayah Khisbiyah, Ibnu Hadjar dan Jeny Elna. Ruswan meneliti perbandingan sikap toleransi beragama mahasiswa yang hanya menerima mata kuliah Agama Islam (Wahid Hasyim) dengan mahasiswa yang menerima mata kuliah agama-agama (Akademi Kebidanan). Hasil uji statistik menunjukkan mahasiswa yang mempelajari agama-agama memiliki sikap toleransi yang lebih tinggi dibandingkan dengan mereka yang hanya mempelajari satu agama saja. ${ }^{36}$

Senada dengan Ruswan, Jeny Elna menemukan adanya korelasi antara pendidikan agama berwawasan pluralis dengan peningkatan sikap, perilaku dan wawasan pluralitas siswa. Jeny yang melakukan penelitian di sekolah dan madrasah di Bali juga menemukan bahwa kualitas penyelenggaraan pendidikan agama di sekolah masih rendah karena sistem dan kurikulumnya tidak mengakomodir perbedaan latar belakang agama dan kebudayaan siswa. ${ }^{37}$

Listia, dkk., membandingkan tiga model pendidikan agama alternatif: model religiusitas (Keuskupan Agung Semarang), model inklusif (SMA PIRI I Yogyakarta), dan model komunikasi iman (SMA BOPKRI 1 Yogyakarta). Ketiga model alternatif tersebut dikembangkan dengan mempertimbangkan kebutuhan siswa yang majemuk dan penekanan aspek partisipatoris. Listia menemukan dua kesimpulan penting tentang hubungan model pendidikan agama dengan sikap toleransi. Pertama, model pendidikan alternatif yang dikembangkan tiga sekolah penelitian berpengaruh positif terhadap pembentukan sikap toleran. Kedua, model pemisahan (segregasi) yang dikembangkan pemerintah sesuai dengan UUSPN berpotensi memupuk benihbenih intoleransi dan diskriminasi. ${ }^{38}$

Yayah Khisbiyah dkk. dari Universitas Muhammadiyah Surakarta (UMS) 
meneliti pendidikan apresiasi seni untuk pluralisme budaya di Madrasah Ibtidayah Muhammadiyah (MIM) di Surakarta dan Sumatera Barat. Penelitian eksperimen ini membuktikan bahwa pendidikan apresiasi seni berpengaruh terhadap pembentukan identitas diri dan pluralitas budaya Nusantara sehingga mereka dapat menerima dan menghormati pluralitas bangsa. Penelitian ini juga menolak asumsi bahwa kelompok modernis kurang apresiatif terhadap pluralitas dan kebudayaan lokal. ${ }^{39}$

Lembaga-lembaga pendidikan Islam-madrasah dan pesantren-telah lama memiliki konsep dan tradisi pluralisme. Penelitian Fuad Fachruddin dan Badrus Sholeh menjelaskan berkembangnya kultur pluralisme dalam masyarakat Muslim. Dalam penelitiannya, Fachruddin menemukan perbedaan pandangan antara kelompok "rejeksionis" dan "akomodatif" di kalangan anggota Muhammadiyah dan Nahdlatul Ulama (NU) tentang demokrasi, jender, toleransi dan pluralisme. Meskipun kedua kelompok berbeda sikap terhadap demokrasi, jender dan toleransi, baik Muhammadiyah maupun NU memahami pluralisme sebagai penghargaan atau memberi kesempatan kepada pemeluk agama lain untuk hidup berdampingan secara damai. ${ }^{40}$

Bagaimana lembaga pendidikan Islam berperan dalam demokrasi, civil society dan pluralisme dijelaskan dalam penelitian Badrus Soleh (LP3ES) dan Yayah Khisbiyah. Badrus Soleh menemukan variasi sikap kalangan pesantren terhadap konsep ukhuwah: basyariyah, wathoniyah dan Islamiyah dalam hubungannya dengan sikap terhadap keragaman suku, agama dan budaya. Beberapa pesantren seperti Cipasung (Tasikmalaya), Istiqlal (Cianjur), Edi Mancoro (Salatiga) bersikap positif terhadap kemajemukan. Sedangkan tiga pesantren lainnya: Ngruki (Surakarta), Nurul Hakim (NTB-Kediri) dan DDI (Mangkoso-Sulsel) lebih menyukai keseragaman daripada keragaman. ${ }^{41}$

Bagaimana dengan sekolah Muhammadiyah? Sebutan Muhammadiyah sebagai gerakan Islam puritan yang menyerukan pemurnian Islam dari sinkretisme, bid'ah, khurafat dan anasir lain yang merusak agama serta prinsip berpegang teguh kepada tauhid yang murni, al-Qur'an dan Hadits yang shahih sering mengesankan bahwa Muhammadiyah merupakan gerakan yang eksklusif. Muhammadiyah dinilai sebagai gerakan radikal dan tidak toleran, terutama terhadap tradisi lokal dan misionaris Kristen/Katolik. Tetapi, penelitian Mitsuo Nakamura, James L Peacock, Achmad Jainuri dan Alwi Shihab menunjukkan bahwa meskipun Muhammadiyah sangat menekankan pengamalan Islam yang murni, para pendiri dan tokoh Muhammadiyah bersikap terbuka dan toleran terhadap tradisi masyarakat dan pemeluk agama 
lain, khususnya Kristen/Katolik.

Dalam penelitiannya, Nakamura menemukan empat paradoks dalam Muhammadiyah. Sebagai gerakan reformasi Islam yang berusaha memurnikan ajaran Islam Muhammadiyah justru mendapat dukungan kuat di jantung pusat tradisi kebudayaan Jawa. Para tokoh dan anggota yang menjadi pendukung Muhammadiyah bukanlah kalangan santri yang taat beragama (religiously devout) dan kaum pribumi borjuis (indigenous bourgoisie). Ideologi Muhammadiyah bukanlah merupakan difusi kultural gerakan reformasi Islam Timur Tengah tetapi transformasi internal tradisi religio-ethical Jawa, generalisasi dan rasionalisasi tradisi. ${ }^{42}$ Meskipun interaksi Muhammadiyah dengan budaya Jawa diwarnai beberapa ketegangan, secara keseluruhan gerakan reformasi Islam ini memiliki apresiasi dan toleransi yang tinggi terhadap tradisi Jawa. ${ }^{43}$

Dalam konteks dan fokus kajian yang berbeda, Achmad Jainuri menemukan akar-akar toleransi dan pluralisme dalam Muhammadiyah. Penelitiannya tentang ideologi Muhammadiyah menunjukkan bahwa sebagai gerakan reformasi yang menganjurkan kehidupan berdasarkan tauhid yang murni dan keteguhan berpedoman kepada al-Qur'an dan Hadits Muhammadiyah memiliki ideologi sosial yang terbuka. Ideologi pluralisme dalam Muhammadiyah berakar pada prinsip relativisme pemahaman agama dan ijtihad. Dengan prinsip relativisme tersebut, Muhammadiyah terbuka terhadap paham dan ide-ide baru dari mana pun datangnya. Keterbukaan Muhammadiyah terhadap pluralisme keagamaan nampak jelas dalam pembaharuan pendidikan Muhammadiyah yang meliputi: adopsi sistem sekolah model Belanda, pengajaran studi sekuler dan diterimanya siswa nonmuslim (Kristen) dan abangan dalam sekolah Muhammadiyah. Reformasi pendidikan Muhammadiyah memiliki bangunan ideologis yang kuat berdasarkan pemahaman tentang iman, amal shalih, birr, amar ma'ruf nahi munkar dan fastabiq al-khairat. ${ }^{44}$ Karena itu, sikap kritis dan resistensi Muhammadiyah terhadap misi Kristenisasi di Indonesia tidak didasarkan di atas prinsip rivalitas dan permusuhan, tetapi persaingan, kompetisi yang sehat, dialog dan saling menghormati secara jujur. ${ }^{45}$

Penelitian lain tentang Muhammadiyah yang cukup penting adalah karya Alfian, MT. Arifin dan Amir Hamzah Wirjosukarto. Dalam disertasinya, Alfian menjelaskan secara jelas bagaimana sikap politik Muhammadiyah terhadap kebijakan politik pemerintah. Meskipun dalam beberapa hal bersikap kooperatif, Muhammadiyah menentang sangat keras kebijakan pemerintah kolonial yang kontraproduktif terhadap kebebasan beragama, salah satunya Ordonansi Guru. ${ }^{46}$ 
MT. Arifin ${ }^{47}$ dan Amir Hamzah ${ }^{48}$ mengkaji secara filosofis dan historis pembaharuan Muhammadiyah dalam Pendidikan. Keduanya memaparkan pergulatan Muhammadiyah dalam bidang pendidikan dan kontribusinya dalam memajukan bangsa.

Kajian penting yang membahas pandangan Muhammadiyah mengenai pluralisme adalah Tafsir Tematik Al-Qur'an yang diterbitkan oleh Majelis Tarjih dan Pengembangan Pemikiran Islam. Buku yang merupakan hasil dari Rapat Kerja Nasional (Rakernas) Majelis Tarjih tersebut memberikan kajian tafsir yang sangat luas dan mendalam mengenai hubungan sosial antar umat beragama. Secara keseluruhan, buku ini menunjukkan keterbukaan Muhammadiyah terhadap pluralisme khususnya menyangkut pandangannya mengenai Ahli Kitab, kerjasama antarumat beragama, keadilan sosial dan pernikahan antaragama. ${ }^{49}$

Meski demikian, sebagai organisasi yang terbuka, Muhammadiyah memiliki pluralitas internal yang dinamis. Sikap para aktivis dan anggota Muhammadiyah terhadap perbedaan keyakinan dan pluralisme tidaklah sama dan monolitik. Penelitian Abdul Munir Mulkhan, Boy Paradana dan Biyanto secara jelasa menggambarkan dinamika internal tersebut. Tesis Boy Pradana di Australian National University (ANU) memaparkan secara jelas konstelasi pemikiran dalam Muhammadiyah antara kelompok "konservatif" versus "progresif". Boy menyimpulkan bahwa paska Muktamar ke 45 di Malang, Muhammadiyah cenderung lebih konservatif dan tertutup terhadap gagasan-gagasan pembaruan. Lahirnya kelompok progresif seperti Jaringan Intelektual Muda Muhammadiyah (JIMM) merupakan respons atas stagnasi pemikiran dan lambannya Muhammadiyah dalam menjawab berbagai isu penting di masyarakat. Isu sentral yang menjadi pangkal perdebatan adalah pluralisme agama dan manhaj Muhammadiyah. Bagi kelompok konservatif, tidak ada pluralisme di dalam Islam karena bertentangan dengan tauhid. Sebaliknya, menurut kelompok progresif, pluralisme agama mencerminkan semangat dasar Islam untuk membangun hubungan toleransi, saling menghormati dan mengakui perbedaan dengan agama lain. ${ }^{50}$

Dalam disertasinya, Biyanto menjelaskan sikap dan pandangan para aktivis Muhammadiyah mengenai pluralisme. Biyanto membandingkan dua kutub dalam Muhammadiyah yang dapat menerima dan menolak pluralisme dengan mengangkat isu-isu keagamaan seperti kasus Ahmadiyyah, kebebasan beragama, dll. Dalam penelitiannya, Biyanto menyimpulkan latar belakang pendidikan dan literatur memiliki pengaruh terhadap pembentukan pola 
pemikiran para aktivis. Menariknya, baik kelompok yang menerima maupun yang menolak pluralisme merujuk kepada tokoh-tokoh Muhammadiyah masa awal dan interpretasi terhadap sikap organisasi mengenai isu-isu keagamaan. ${ }^{51}$

Pluralitas sikap keagamaan dan politik warga Muhammadiyah dijelaskan dalam penelitian Abdul Munir Mulkhan. Dalam penelitiannya, Abdul Munir Mulkhan menemukan adanya empat kelompok dalam Muhammadiyah. Pertama, Muhammadiyah al-Ikhlas. Kelompok ini memiliki orientasi keagamaan yang menekankan aspek akidah dan purifikasi ajaran Islam dengan menentang keras takhayul, bid'ah, khurafat (TBK), tradisi lokal dan cenderung konfrontatif terhadap pemeluk agama lain. Kedua, Muhammadiyah Kiai Dahlan. Kelompok ini bersikap rasional dan memahami agama secara terbuka. Mereka mengamalkan ajaran Islam yang murni tetapi bersikap toleran terhadap kelompok lain serta dapat memahami praktikTBK. Ketiga, kelompok Munu (Muhammadiyah-NU). Kelompok ini bergabung dengan Muhammadiyah karena amal-amal sosialnya. Meskipun telah menjadi anggota Muhammadiyah mereka masih memegang teguh tradisi keagamaan sebagaimana warga Nahdlatul Ulama. Keempat, kelompokMarmud (Marhaenis-Muhammadiyah). Kelompok ini agak dekat dengan tradisi abangan. Sebagian mereka bahkan masih terbiasa menyelenggarakan tradisi keagamaan dan kebudayaan yang cenderung sinkretis. Orientasi politiknya sangat nasionalis. Mayoritas anggota Muhammadiyah adalah kelompok Munu yang terdiri atas para petani yang tekun dan menjadikan TBC (takhayul, bid'ah dan churafat) sebagai tradisi. Elit pimpinan cabang didominasi kelompok Kiai Dahlan. Al-Ikhlas dan Marmud sama-sama menjadi kelompok minoritas di kalangan warga Muhammadiyah. Berdasarkan penelitian Abdul Munir Mulkhan, konfigurasi warga Muhammadiyah didominasi oleh kelompok pluralis yang toleran terhadap tradisi. ${ }^{52}$

\section{PLURALISME DAN PENDIDIKAN MUHAMMADIYAH}

Secara esensial dan perenial model institusi, sistem, karakter dan kultur pendidikan Muhammadiyah masa kini berakar pada ideologi Muhammadiyah sebagai dasar normatif dan pengalaman historis sebagai landasan empiris. Ideologi Muhammadiyah adalah sistem paham, falsafah atau world view yang mendasari perjuangan melaksanakan gerakan untuk mencapai tujuan. ${ }^{53}$ Ideologi Muhammadiyah bersumber pada al-Qur'an dan As-Sunnah yang secara formal-organisasi terhimpun dalam Mukadimah Anggaran Dasar, Kepribadian Muhammadiyah, Matan Keyakinan dan Cita-Cita Hidup Muhammadiyah (MKCH), Khitah Perjuangan, Pedoman Hidup Islami (PHI) dan pedoman lain 
yang mendukung nilai-nilai ideologis. ${ }^{54}$ Pengalaman historis adalah produk ijtihad dan kreativitas strategis dalam konteks tertentu di masa lalu yang relevan dengan konteks sekarang. Implementasi ideologi bersifat relatif permanen dan mengikat setiap amal usaha Muhammadiyah. Sedangkan pengalaman sejarah bersifat kasuistik dan tidak mengikat.

Ada tiga pokok masalah yang akan dibahas. Pertama, Muhammadiyah sebagai gerakan Islam dan dakwah amar ma'ruf nahi munkar. Muhammadiyah memahami dakwah sebagai proses Islamisasi kultural. Kedua, pemahaman Muhammadiyah tentang pluralisme dan toleransi. Bagian secara spesifik menguraikan ideologi Muhammadiyah sebagai gerakan Islam yang puritanpluralis. Ketiga, implementasi konsep dakwah dan pluralisme dalam pendidikan Muhammadiyah. Bagaimana pluralisme berkembang dalam tradisi pendidikan Muhammadiyah secara ringkas dibahas dalam bagian ini.

\section{MUHAMMADIYAH: PURITAN YANG PLURALIS}

Sesuai dengan MKCH, "Muhammadiyah bekerja untuk tegaknya akidah Islam yang murni, bersih dari gejala-gejala kemusyrikan, bid'ah dan khurafat, tanpa mengabaikan prinsip toleransi menurut ajaran Islam. "55 Bagaimanakah pandangan Muhammadiyah tentang toleransi dan pluralisme?

Pandangan Muhammadiyah tentang pluralisme dan toleransi dapat dikaji dari tiga perspektif. Pertama, pandangan Muhammadiyah tentang kehidupan bermasyarakat. Kedua, prinsip-prinsip dan dasar-dasar keagamaan dalam Muhammadiyah. Ketiga, usaha-usaha Muhammadiyah dalam membangun persatuan dan relasi dengan umat non-Muslim. Perspektif pertama dan kedua lebih bersifat ideologis. Sedangkan yang ketiga mengkaji secara historis dengan melihat kiprah organisasi dan para tokoh.

Muhammadiyah berpendapat bahwa hidup bermasyarakat adalah sunnatullah dan bagian dari ibadah, Sesuai dengan fitrahnya, manusia adalah makhluk sosial. Hidup bermasyarakat adalah takdir, perwujudan qudrat-iradat Allah. ${ }^{56}$ Terkait dengan matan ini, Hamdan Hambali menjelaskan bahwa hidup bermasyarakat adalah kodrat (ketentuan) Allah untuk memberi makna dan nilai yang hakiki bagi kehidupan manusia. Betapa pun sangat sempurna, manusia yang individualistis tidak mampu meraih makna dan nilai kehidupan. Hidup bermasyarakat memiliki makna transendental sebagai bagian dari ibadah, pengabdian kepada Allah Tuhan Yang Maha Esa. ${ }^{57}$

Karena itu Muhammadiyah mendorong anggotanya untuk aktif terlibat dalam kehidupan masyarakat. Sesuai dengan Pedoman Hidup Islami (PHI) 
warga Muhammadiyah agar senantiasa menjalin persaudaraan dan tidak diskriminatif dengan sesama anggota masyarakat. Berdasarkan akhlak Islam, dalam kehidupan bertetangga warga Muhammadiyah hendaknya memelihara hak, menjunjung tinggi kehormatan dan membina hubungan yang harmonis baik kepada sesama Muslim maupun non-Muslim. ${ }^{58}$

Khusus tentang hubungan bertetangga dengan non-Muslim, PHI memberikan guideline agar warga Muhammadiyah berinteraksi secara alamiah dan bersikap toleran.

Dalam bertetangga dengan yang berlainan agama juga diajarkan untuk bersikap baik dan adil, mereka memperoleh hak-hak dan kehormatan sebagai tetangga, ${ }^{59}$ memberi makanan yang halal dan boleh pula menerima makanan dari mereka berupa makanan yang halal, dan memelihara toleransi sesuai dengan prinsip-prinsip yang diajarkan agama Islam. ${ }^{60}$

Keterlibatan manusia dalam kehidupan masyarakat mencerminkan kualitas keimanan. Menurut K.H. Mas Mansur, kehadiran seorang mukmin di dalam masyarakat harus bermanfaat, menimbulkan kebahagiaan dan kedamaian. ${ }^{61}$ Mas Mansyur menjelaskan hal ini dengan mengutip beberapa Hadits, antara lain riwayat Abu Nai'm dari Ibnu Umar: "Orang mukmin itu bermanfaat, kalau engkau berjalan dengannya dia memberi manfaat, jika diminta pendapat dia memberi manfaat, jika bergaul dengannya dia memberi manfaat, semua hal yang datang darinya bermanfaat."

Hidup bermasyarakat merupakan bagian tak terpisahkan dari Aqidah Tauhid. Amien Rais memformulasikan hal ini dalam konsep Tauhid Sosial. ${ }^{62}$ Menurutnya, Tauhid secara spiritual-vertikal berarti mengesakan Allah sebagai satu-satunya Tuhan di alam semesta. Tauhid berarti memusatkan segala sesuatu kepada Allah (centrality on God) sebagai poros (axis) dalam kehidupan. Selain makna ekslusifnya, Tauhid juga memiliki makna yang inklusif: mempersatukan. Dalam konteks ini, Tauhid memiliki lima dimensi. Pertama, unity of God (kesatuan Tuhan); Allah adalah Tuhan bagi seluruh alam semesta. ${ }^{63}$ Kedua, unity of guidance (kesatuan tuntunan/petunjuk hidup); al-Qur'an adalah petunjuk bagi seluruh umat manusia. ${ }^{64}$ Ketiga, unity of creation (kesatuan penciptaan/makhluk); semua yang eksis di alam semesta selain Allah adalah makhluk. Manusia tidak boleh berbuat kejahatan kepada sesama manusia, binatang dan merusak alam semesta karena mereka semua adalah makhluk Allah. ${ }^{65}$ Keempat, unity of mankind (kesatuan umat manusia); umat manusia adalah satu, tidak ada superioritas individu, kelompok, suku dan lain-lain kecuali atas takwa. ${ }^{66}$ Kelima, unity of the purpose of life (kesatuan tujuan 
hidup). Pada dasarnya setiap manusia ingin mendapatkan kebahagiaan dalam kehidupan. Karena itu manusia tidak boleh merampas hak sesama dengan berbuat kerusakan demi kebahagiaannya sendiri. ${ }^{67}$

Dengan demikian, Tauhid yang murni bukanlah jalan kehidupan yang ekslusif-individualistik. Tauhid yang murni justru menumbuhkan sikap terbuka dan semangat persatuan di antara manusia yang berbeda-beda agama dan keyakinan. Untuk menciptakan persatuan, manusia harus meninggalkan sikap egoistis, merasa dirinya paling benar dan meninggalkan musyawarah. Menurut $\mathrm{KRH}$. Hadjid, prinsip persatuan inilah yang sangat ditekankan oleh K.H. Ahmad Dahlan. "kebanyakan diantara para manusia berwatak angkuh dan takabur, mereka mengambil keputusan sendiri-sendiri. " ${ }^{68}$ Egoisme pribadi dan kelompok itulah sumber perpecahan dan kehancuran masyarakat.

Untuk menciptakan persatuan dan harmoni sosial diperlukan dialog, sikap terbuka dan saling menghormati di antara sesama warga masyarakat yang berbeda-beda agama dan keyakinan. K.H. Ahmad Dahlan mengkritik keras sikap egoisme dengan mengatakan:

... marilah mengadakan permusyawaratan dengan golongan lain di luar golongan masing-masing untuk membicarakan manakah sesungguhnya yang benar itu dan manakah sesungguhnya yang salah.

... satu macam agama, menganggap salah terhadap sebagian golongan yang lain. Misalnya, mereka yang beragama Kristen Katolik menganggap salah mereka yang beragama Kristen Protestan. Sebaliknya kaum Kristen Protestan juga menyalahkan kaum Kristen Katolik.

Begitu juga di kalangan umat Islam, mereka yang mengaku sebagai Ahli Sunnah wal Jama'ah menetapkan salah terhadap mereka yang didakwa termasuk golongan Mu'tazilah...

Pendek kata, tiap-tiap golongan dari yang besar sampai yang kecil, malah sampai kepada perseorangan, mereka menganggap bahwa dirinya yang benar dan sudah benar, kemudian menyalahkan kepada yang lainnya.

Mereka merasa sudah benar, tidak memerlukan lagi untuk mengetahui keadaaan golongan lain, tidak memerlukan bermusyawarah dengan golongan lain, dan mengabaikan hujjah atau alasan golongan lain. ${ }^{69}$

Selanjutnya, K.H. Ahmad Dahlan juga mengkritik kecenderungan umat beragama yang memutlakkan kebenaran keyakinannya dan menyerang pemeluk agama lain. K.H. Ahmad Dahlan menganalogikan sikap tersebut sebagaimana orang yang melempar pisau cukur untuk melukai orang lain: "Manusia satu 
sama lain selalu melemparkan pisau cukur, mempunyai anggapan pasti paling tepat, dia melemparkan celaka kepada orang lain." 70 Inti pendapat K.H. Ahmad Dahlan tersebut dijelaskan KRH. Hadjid sebagai berikut:

Sebagaimana orang Yahudi yang menganggap bahwa dirinya akan bahagia, dan selain orang Yahudiakan sengsara, begitu juga orang Kristen yang menganggap bahwa hanya golongannya yang akan bahagia, mendapat surga, lainnya akan sengsara.

Begitulah anggapan tiap-tiap golongan agama, seperti hanya golongan Majusi, golongan Shabiah dan lain-lainnya lagi.... Golongan Islam juga menetapkan demikian. Hanya golongan Islam yang selamat dari api neraka, sedang selain golongan Islam akan sengsara.

Sekarang bagaimana dengan orang yang tidak beragama?

... oleh golongan-golongan yang beragama baik golongan Islam, Yahudi, Kristen, Majusi, dan agama-agama lain, diyakini bahwa orang yang tidak beragama itu semua akan celaka dan sengsara.

Namun, sebaliknya, golongan yang tidak beragama mempunyai anggapan, bahwa manusia itu sesudah mati tidak akan celaka, tidak akan disiksa. ${ }^{71}$

Muhammadiyah menginginkan tatanan masyarakat yang integratif, tidak tersekat-sekat oleh perbedaan suku, bangsa dan agama dengan mengembangkan sikap saling menghormati dan hidup rukun dengan sesama. Muhammadiyah menghendaki terwujudnya masyarakat madani yang pluralistik. Setiap warga Muhammadiyah hendaknya bisa menjadi pribadi teladan. "... pribadi manusia dan ketertiban hidup bersama adalah merupakan unsur pokok dalam membentuk dan mewujudkan masyarakat yang baik, bahagia dan sejahtera." ${ }^{12}$ Muhammadiyah berusaha membangun masyarakat yang pluralistik dengan mengembangkan sikap pluralis.

Sikap pluralis di dalam Muhammadiyah memiliki tiga landasan ideologis. Pertama, dalam bidang keagamaan Muhammadiyah tidak terikat kepada salah satu mazhab. Kedua, Muhammadiyah meyakini paham relativisme pemikiran dimana kebenaran suatu pemikiran atau hasil ijtihad bersifat subyektif-relatif dan terbuka untuk dikaji ulang. Ketiga, dalam bidang muamalah-duniawiyah (sosial-kemasyarakatan) Muhammadiyah memiliki prinsip "open learning": keterbukaan untuk belajar dari berbagai sumber.

Muhammadiyah menyatakan dirinya tidak terikat kepada salah satu mazhab. Menurut Muhammadiyah, hasil ijtihad para ulama yang terkodifikasi 
menjadi mazhab merupakan "paham agama" yang tidak mengikat, ${ }^{73}$ bukan doktrin agama yang harus diikuti. Pernyataan ini tidak berarti Muhammadiyah menolak pendapat para imam Mazhab. Dalam bidang fikih, K.H. Ahmad Dahlan terpengaruh oleh Mazhab Syafi'i. Mayoritas guru-gurunya ketika menunaikan ibadah haji dan bermukim di Mekah selama lebih dari setahun adalah para syeikh Mazhab Syafi'i seperti Kyai Nawawi Muhtaram Banyumas, Kyai Nawawi al-Bantani dan Sayyid Bakri Shatta. K.H. Ahmad Dahlan juga belajar kepada para ulama Nusantara yang bermukim di Mekah seperti Kyai Mahfudz Termas dan Ahmad Khatib Minangkabau. ${ }^{74}$ Nama Ahmad Dahlan sebagai pengganti Muhamm ad Darwisy-nama kecil Ahmad Dahlan-diberikan oleh Syeikh Sayyid Bakri. ${ }^{75}$ Ada dua kemungkinan mengapa Sayyid Bakri memberikan nama Ahmad Dahlan. Pertama, Sayyid Bakri mengharapkan K.H. Ahmad Dahlan menjadi pewaris dan penerus ajaran Ahmad Ibn Zaini Dahlan ${ }^{76}$ di Indonesia. Dalam tradisi Islam, nama adalah doa agar seseorang mendapat berkah dan dapat menjadi manusia sebagaimana namanya. Kedua, Sayyid Bakri memberikan nama "asal saja", tidak memiliki agenda apa pun. ${ }^{77}$

Pengaruh Mazhab Syafi'i dalam figh K.H. Ahmad Dahlan dan Muhammadiyah masa awal dapat dilihat dari beberapa aspek. Pertama, dalam bidang ibadah K.H. Ahmad Dahlan membaca doa qunut dalam setiap salat shubuh. Bilangan Salat Tarawih dua puluh rakaat. Kedua, dalam tradisi keagamaan rapat-rapat resmi dan pengajian di Muhammadiyah selalu dibuka dan diakhiri dengan bacaan Surat al-Fatihah. Ketiga, bidang ijtihad Muhammadiyah mempergunakan qiyas sebagai metode instinbat hukum yang utama. ${ }^{78}$ Tetapi dalam hal menyangkut batalnya wudlu, misalnya menyentuh perempuan, Muhammadiyah lebih condong kepada pendapat Imam Hanafi yang berpendapat sentuhan perempuan tidak membatalkan wudlu.

Dengan tidak bermazhab, Muhammadiyah dapat bersikap "netral" dan bergerak bebas tanpa terbelenggu oleh suatu pendapat. Muhammadiyah berusaha melakukan revitalisasi al-Qur'an dan As-Sunnah sebagai sumber hukum yang universal. Dalil-dalil al-Qur'an harus lebih diutamakan daripada pendapat para imam mazhab. Tanpa mengurangi penghargaan kepada para ulama dan pendapatnya, Muhammadiyah menilai ijtihad para ulama klasik memiliki keterbatasan. Pertama, keterbatasan intelektual yang bermuara pada otentisitas dan validitas referensi dalil-dalil rujukannya. Kedua, keterbatasan relevansi dengan kehidupan kontemporer karena perbedaan konteks, ruang dan waktu. Tidak bermazhab bukan berarti talfiq-mencampuraduk pendapat Mazhab-atau mencari yang mudah-mudah saja dalam beragama tetapi 
mengikuti pendapat yang paling kuat di antara pendapat para ulama sebagai hujjah dalam beribadah. Secara khusus Muhammadiyah melembagakan tradisi ijtihad melalui Majelis Tarjih yang bertugas melakukan pengkajian sehingga seluruh amal ibadah Muhammadiyah sesuai dengan dalil al-Qur'an dan Hadits yang rajih (kuat).

Menurut Muhammadiyah pintu ijtihad senantiasa terbuka. Hasil-hasil pemikiran dan tafsir ulama terdahulu terbuka untuk dikaji kembali. Meskipun otoritas berijtihad tetaplah terbatas. Otoritas ijtihad hanya diberikan kepada mereka yang berkompeten, baik secara induvidual maupun kolektif. Tetapi, setiap manusia berkewajiban untuk meningkatkan pengetahuan dan mendalami ajaran agama. Menurut K.H. Mas Mansur, para ulama yang berkompeten hendaknya senantiasa berijtihad untuk memperluas dan memperdalam agama. Bagi masyarakat yang tidak berkompeten boleh berittiba', mempelajari agama kepada para ulama sehingga memahami dalildalil secara mendalam. ${ }^{79}$ Muhammadiyah mengajak umat Islam membebaskan diri dari stagnasi pemikiran dan disintegrasi sosial sebagai warisan sejarah Islam masa pertengahan, ${ }^{80}$ dengan memperluas paham agama dan tidak berhenti berijtihad terutama dalam lapangan sosial.

Sebagai produk pemikiran, kebenaran hasil ijtihad kolektif (ijtihad jamai') dan ijtihad individual (ijtihad munfarid) bersifat subyektif dan relatif. Berdasarkan prinsip keagamaan yang kedua ini, Muhammadiyah berpendapat bahwa tidak ada hasil ijtihad yang final. Semuanya terbuka untuk dikaji kembali dan direvisi, termasuk yang dikemukakan oleh Muhammadiyah sendiri. Fakta historis mengenai hal ini adalah perubahan fatwa Majelis Tarjih tentang doa qunut dan pemasangan foto K.H. Ahmad Dahlan. Majelis Tarjih menyatakan bahwa doa qunut bukan bagian dari salat shubuh. Pendapat ini berbeda dengan fatwa terdahulu yang memperbolehkan qunut dalam setiap salat shubuh. Atas alasan syaddu al-dzari'ah (preventif) Majelis Tarjih masa awal melarang pemasangan foto K.H. Ahmad Dahlan karena bisa menjurus kepada kemusyrikan (kultus individu), Di kemudian hari, ketika akidah umat sudah kuat, foto K.H. Ahmad Dahlan boleh dipasang untuk tujuan pendidikan (tarbiyah). ${ }^{81}$ Perubahan fatwa bukan hal yang asing. Ketika bermukim di Baghdad, Imam Syafi'i memperbolehkan transaksi "salam"82 karena penduduknya jujur. Fatwa ini disebut qaul al-qadîm. Ketika hijrah dan menetap di Mesir, Imam Syafi'i melarang transaksi bisnis "salam". Mayoritas masyarakat Mesir cenderung curang, tidak dapat dipercaya. Fatwa baru ini disebut qaul al-jadîd. 
Muhammadiyah juga berpendapat bahwa hasil ijtihad tidak pernah tunggal. Muhammadiyah menyadari adanya pluralitas pemikiran dan keagamaan di dalam masyarakat. Karena itu, dalam setiap pernyataannya Muhammadiyah selalu mengemukakan: "ini adalah pendapat Muhammadiyah". Pernyataan ini mengandung pengertian bahwa dalam masalah yang sama sangat dimungkinkan adanya pendapat kelompok lain yang berbeda. Di antara perbedaan pendapat yang ada, Muhammadiyah tidak mengklaim pendapatnyalah yang paling valid. ${ }^{83}$

Muhammadiyah memahami dan menerima pluralitas sebagai keniscayaan sosiologis. Setiap manusia akan cenderung membela dan mempertahankan pendapat dirinya dan kelompoknya. K.H. Ahmad Dahlan menggambarkan kecenderungan ini dengan merujuk kepada al-Qur'an Qs. 30, Ar-Rum: $32 .{ }^{84}$ Bahkan, karena fanatisme yang berlebihan manusia menutup diri dan membenci pihak lain: "Manusia itu semua membenci sesuatu yang tidak diketahui" ${ }^{85}$ Perbedaan ideologis dan kultural dalam suatu masyarakat "... harus dipelihara sejauh perbedaan ini tidak bertentangan dengan nilai dan norma dasar yang dianut oleh masyarakat itu. ${ }^{86}$

Lebih jauh dari itu, Muhammadiyah menerima pluralitas sebagai bagian dari sunnatullah. Pendapat Muhammadiyah ini berdasarkan pemahaman komprehensif ayat-ayat al-Qur'an, khususnya Qs. 2, al-Baqarah: 148 dan Qs. 5, al-Maidah: $48 .{ }^{87}$ Menurut Majelis Tarjih dan Pengembangan Pemikiran Islam (PPI) di dalam al-Qur'an terdapat apresiasi terhadap pluralisme agama melalui pengakuan bahwa tiap-tiap umat beragama mempunyai pandangan, orientasi, dan praktik keagamaan masing-masing. Merujuk kepada pendapat al-Qurthubi, Majelis Tarjih dan PPI menyimpulkan bahwa "keragaman itu merupakan sesuatu yang memang menjadi tujuan Tuhan dalam ciptaanNya." ${ }^{\prime 8}$

Manusia harus mengambil manfaat dari pluralitas dengan sikap saling menghormati dan berdialog secara tulus. Dialog bukanlah dimaksudkan untuk mencari titik temu di antara agama yang berbeda-beda, tetapi lebih difokuskan sebagai upaya untuk mengenal "yang lain". Dialog bukan bertujuan untuk melakukan "asimilasi":89 melebur kelompok-kelompok yang berbeda-beda. Semangatnya bukanlah untuk menunjukkan superioritas satu kelompok di atas yang lainnya (menang-kalah), tetapi saling mempelajari (mutual understanding). Sebagaimana ditulis KRH. Hadjid, K.H. Ahmad Dahlan mengatakan:

Manusia itu perlu sekali mendengarkan segala fatwa ucapan. Dari siapa saja harus didengar. Jangan sampai menolak, tidak mau 
mendengarkan suara dari lain pihak. Selanjurnya suara-suara tadi harus dipikir sedalam-dalamnya, dan ditimbang, disaring dan dipilih yang benar.

Manusia perlu mengetahui mana yang benar dan mana yang salah. Manusia yang tahu caranya mencuri, tidak dapat disebut sebagai pencuri kecuali kalau memang benar-benar dia itu mencuri. Begitu juga seorang Kristen yang paham seluk-beluk tentang agama Islam, belum menjadi orang Islam kecuali kalau dia itu benar-benar mengamalkan agama Islam. Dan sebaliknya orang Islam pun yang tahu seluk-beluk tentang agama Kristen juga tidak lalu menjadi Kristen, kecuali kalau memang mengamalkannya. ${ }^{90}$

Keterbukaan untuk bersedia belajar dan menerima pihak lain yang berbeda membutuhkan sikap toleransi. K.H. Ahmad Dahlan pernah mengundang para tokoh wanita Sarekat Islam untuk berbicara di forum pengajian Aisyiah. Dalam kesempatan lain, K.H. Ahmad Dahlan memberikan kesempatan kepada dua tokoh Sosialis, Soedarsono dan Sema'un, untuk berbicara di rapat terbuka Muhammadiyah. Dalam pidatonya, kedua tokoh Sosialis tersebut banyak mengkritik pemerintah dan memaparkan gagasan "komunisme": sama rata sama rasa. K.H. Ahmad Dahlan harus membayar mahal langkah "kontroversial" itu. Para priyayi "borjuis" yang dekat dengan kekuasaan pemerintah Belanda mengundurkan diri dari Muhammadiyah karena menilai K.H. Ahmad Dahlan dengan dengan kaum Sosialis Kiri. Biasanya rapat-rapat dan pengajian Muhammadiyah selalu dibuka dan ditutup dengan bacaan Surat al-Fatihah. Tetapi, untuk kesempatan tersebut-pidato Soedarsono dan Sema'un-rapat dibuka dan ditutup dengan ketok palu, bukan al-Fatihah. ${ }^{91}$ Apa yang dilakukan Muhammadiyah ini merupakan contoh toleransi dan pluralisme positif.

Ada dua hal penting yang perlu dicatat dari langkah K.H. Ahmad Dahlan. Pertama, dari perspektif ideologis dan sosiologis, K.H. Ahmad Dahlan tidak menghendaki Muhammadiyah sebagai organisasi yang ekslusif: untuk masyarakat kelas menengah terpelajar, priyayi dan aristokrat. Sebelum mengundang para tokoh Sosialis, K.H. Ahmad Dahlan mengundang para buruh ke Kauman dan sekolah Muhammadiyah. Kedua, dari sudut paedagogis, K.H. Ahmad Dahlan berusaha membangkitkan kesadaran dan militansi para kader Muhammadiyah dan Aisyiyah untuk lebih percaya diri di dalam mengembangkan Muhammadiyah kepada masyarakat. ${ }^{92}$

Pluralisme memerlukan kedewasaan dan sikap inklusif menerima orang lain yang berbeda. Perbedaan pendapat dan keyakinan bukan halangan untuk 
menjalin persahabatan. K.H. Ahmad Dahlan bersahabat dengan Domine Baker, seorang misionaris Kristen di Yogyakarta. Dengan temannya itu K.H. Ahmad Dahlan beberapa kali terlibat dalam perdebatan keagamaan yang serius, tetapi persahabatan keduanya tetap terbina dengan baik. ${ }^{93} \mathrm{~K} . \mathrm{H}$. Mas Mansur seringkali berbeda pendapat dengan K.H. Moechtar-sekretaris Muhammadiyah-dalam masalah-masalah keagamaan. Tetapi keduanya tetap bersahabat dan bekerjasama sehingga perbedaan pendapat pribadi tidak mempengaruhi kemajuan pergerakan Muhammadiyah. ${ }^{94}$

Tradisi toleransi dan pluralisme di dalam Muhammadiyah dapat dilacak dari sikap K.H. Ahmad Dahlan terhadap pemeluk agama Kristen. Posisinya sebagai abdi dalem dan anggota Budi Utomo memungkinkan K.H. Ahmad Dahlan menjalin hubungan persahabatan yang akrab dengan para bangsawan dan bangsa Belanda. Banyak sahabat K.H. Ahmad Dahlan adalah para misionaris dan zending Kristen. Kepada mereka yang beragama Kristen tersebut, K.H. Ahmad Dahlan membina persahabatan pribadi yang sejati. Alfian menggambarkan persahabatan K.H. Ahmad Dahlan sebagai berikut:

In fact, Dahlan himself took an uncommon, and very probably unprecedented, attitude toward ... He visited them, invited them, and exchanged ideas with them privately or in various public debates. Dahlan was extremely tolerant toward the Christians which they interpreted as his receptivity toward their religion. Reverend Baker, for example, even held the opinion that there was a tendency toward syncretism in Dahlan's doctrine of Islamic modernism and Baker felt that Dahlan professed a belief that there was something worthwhile in every religion. ${ }^{95}$

Tidak hanya bersahabat, K.H. Ahmad Dahlan bahkan mengadopsi metode pendidikan dan gerakan orang Kristen. Karena sikapnya itu, K.H. Ahmad Dahlan secara pribadi sering dicap sebagai "Kiyai Kristen" atau "Kiyai Kafir". ${ }^{96}$ Lembagalembaga pendidikan yang didirikan-khususnya sekolah-disebut "sekolah kafir", terutama setelah Muhammadiyah menerima bantuan finansial dari pemerintah Belanda. ${ }^{97}$ Masalah format pendidikan dan strategi gerakan merupakan masalah duniawi yang didalamnya manusia bebas mengembangkan kreativitas. Menurut Muhammadiyah dunia adalah "segala sesuatu yang disebut dalam sabda Rasulullah dengan ucapan: 'engkau lebih mengetahui urusan duniamu', ialah segala perkara yang tidak menjadi tugas diutusnya para Nabi". ${ }^{98}$ Dengan pandangan ini, Muhammadiyah memilah dan memisahkan sesuatu yang substantif dan sesuatu yang bersifat strategis (cara). Imitasi atau duplikasi 
kelompok lain dalam hal-hal strategis tidak bertentangan dengan agama. K.H. Mas Mansur, mencontohkan hal ini dengan seseorang yang memakai jas. Sebagaimana celana, ikat pinggang, dan sepatu, jas adalah pakaian umum yang bisa dipakai siapa saja. Jika orang Kristen mengenakan pakaian tersebut, tidak berarti seseorang menjadi Kristen. Agama mewajibkan manusia menutup aurat, tetapi tidak menjelaskan bagaimana cara menutupnya. Ini adalah wilayah di mana manusia mendapatkan kebebasan berkreativitas. ${ }^{99}$

Terhadap agresivitas misi Kristen, Muhammadiyah menerapkan prinsip gentlemen-competition bukan rivalry-confrontation. Sikap ini berdasarkan pemahaman konsep "fastabiqu al khairat" sebagaimana termaktub dalam Qs. 2, al-Baqarah: 148 dan Qs. 5, al-Maidah: 48 yang disebutkan terdahulu. Pesatnya pengembangan unit-unit pelayanan sosial oleh kelompok Kristen menginspirasi para tokoh Muhammadiyah untuk mendirikan amal usaha Muhammadiyah yang serupa seperti sekolah, rumah sakit, panti asuhan, rumah jompo, organisasi kepanduan dan sebagainya.

Karena itu, semangat gentlemen competition memiliki akar teologis yang sangat mendalam. Amal sosial Muhammadiyah adalah manifestasi konsep amal shalih dan tanggung jawab sosial. Bagaimana implementasi konsep fastabiqu al khairat dalam pengembangan amal sosial Muhammadiyah dapat dijelaskan dari pidato pelantikan K.H. Soedja sebagai ketua bahagian Penolong Kesengsaraan Oemoem (PKO).

Banyak orang di luar Islam (bukan orang Islam) yang sudah berbuat menyelenggarakan rumah-rumah Panti Asuhan untuk memelihara mereka si fakir miskin dan kanak-kanak yatim yang terlantar dengan cara yang sebaikbaiknya hanya karena terdorong dari rasa kemanusiaan saja, tidak karena merasa tanggung jawab dalam masyarakat dan tanggung jawab di sisi Allah kelak di Hari Kemudian.

Kalau mereka dapat berbuat karena berdasarkan kemanusiaan saja, maka saya heran sekali kalau umat Islam tidak dapat berbuat. Padahal agama Islam adalah agama untuk manusia bukan untuk khalayak yang lain. Apakah kita bukan manusia? Kalau mereka dapat berbuat, kena apakah kita tidak dapat berbuat? Hum rijal wa nahnu rijal. ${ }^{100}$

Dalam perkembangan berikutnya, terutama sesudah wafatnya K.H. Ahmad Dahlan, sikap Muhammadiyah terhadap para misionaris Kristen mengalami perubahan yang drastis. Alfian menggambarkan perubahan tersebut dengan ungkapan yang sangat puitis: "The extreme tolerance toward the Christians as was exemplified by Dahlan in the previous period was to be buried to- 
gether with this founder of Muhammadiyah in 1923, since the movement was to drastically depart from that tolerant attitude." "101 (Sikap toleran kepada orang-orang Kristen yang luar biasa sebagaimana dicontohkan K.H. Ahmad Dahlan terkubur bersama jasad pendiri Muhammadiyah itu pada tahun 1923, tahun di mana gerakan Muhammadiyah meninggalkan perilaku toleran secara drastis).

Perubahan-perubahan tersebut disebabkan oleh beberapa faktor. Pertama, perubahan model dan gaya kepemimpinan para tokoh Muhammadiyah. Salah satu tokoh yang sangat berpengaruh setelah wafatnya K.H. Ahmad Dahlan adalah $\mathrm{H}$. Fachroedin, seorang tokoh muda Muhammadiyah yang sangat nasionalis-Islamis-progresif-radikal. ${ }^{102}$ Kedua, faktor politik karena pemihakan pemerintah Belanda terhadap kegiatan misionaris dan hubungan mutualistis di antara keduanya. Kegiatan misionaris Kristen mendapat subsidi dan difasilitasi oleh pemerintah kolonial Belanda. Policy inilah yang membangkitkan semangat antikolonialisme di kalangan umat Muslim yang dimotori oleh Sarikat Islam dan Ahmadiyah. Kedekatan hubungan antara Muhammadiyah dengan Sarikat Islam dan Ahmadiyah-sebelum akhirnya mereka berpisah-merupakan faktor yang menumbuhkan sentimen anti-Kristen di kalangan Muhammadiyah. ${ }^{103}$ Ketiga, pergeseran kultur dalam organisasi Muhammadiyah ke arah ideologisasi gerakan. Fase ideologisasi Muhammadiyah dimulai sejak dibentuknya Majelis Tarjih pada tahun 1927, di mana Muhammadiyah menjadi sangat "Syariah oriented". 104

Dari uraian tersebut dapat disimpulkan bahwa secara ideologis Muhammadiyah sangat menekankan puritanisme teologis, committed dengan penegakan akidah Islam yang murni, Tauhid yang jauh dari kemusyrikan. Tauhid dimaknai sebagai konsep universal yang menumbuhkan sikap inklusif kepada sesama, khususnya dalam bidang sosial-kemasyarakatan. Muhammadiyah menempatkan kehidupan bermasyarakat sebagai manifestasi iman, tanggung jawab sosial dan ibadah kepada Allah.

Dalam kehidupan masyarakat yang pluralistik, Muhammadiyah mengembangkan tradisi keterbukaan: membina dan memelihara harmoni sosial dengan mengembangkan hubungan baik dan saling bekerjasama sesuai dengan tuntunan akhlak Islam. Ideologi pluralisme di dalam Muhammadiyah dibangun di atas tiga pondasi: tidak bermazhab, relativisme kebenaran paham keagamaan dan keterbukaan untuk belajar dari siapa saja. Pada masa-masa awal Muhammadiyah sangat toleran terhadap pemeluk agama lain khususnya Kristen. Sesuai dengan prinsip fastabiqu al khairat, Muhammadiyah bekerja 
keras mengembangkan pelayanan sosial sebagai bentuk gentlemen-competition bukan rivalry-confrontation dengan misionaris Kristen. Dinamika relasi Muhammadiyah dengan Kristen dalam banyak kasus dipengaruhi oleh faktor kepemimpinan internal Muhammadiyah, dinamika politik eksternal organisasi dan ideologisasi gerakan.

Secara ringkas, pandangan Muhammadiyah tentang pluralisme dan toleransi dapat dijelaskan dengan deskripsi Muhammadiyah Kiai Dahlan sebagaimana dikemukakan Abdul Murnir Mulkhan. Muhammadiyah adalah gerakan yang "puritan inklusif substansialis yang lebih mementingkan dimensi etik pemurnian Islam dengan partisipasi dalam lembaga cukup tinggi serta orientasi rasional dalam dunia kerja."105

\section{PENDIDIKAN MUHAMMADIYAH: MEMBANGUN PLURALISME}

Sebagaimana dijelaskan dalam bagian terdahulu, Muhammadiyah adalah gerakan Islam dan dakwah amar ma'ruf nahi munkar yang bertujuan untuk menegakkan dan menjunjung tinggi ajaran Islam menuju terwujudnya masyarakat Islam yang sebenar-benarnya. Seluruh aktivitas Muhammadiyah, termasuk di dalamnya pendidikan, merupakan pengejawantahan dari identitas Muhammadiyah ini. Karena itu, secara fungsional Pendidikan Muhammadiyah memiliki tiga misi agency: pendidikan, dakwah dan perkaderan. ${ }^{106}$

Pendidikan tidak dapat dipisahkan dari dinamika gerakan dakwah Muhammadiyah. Sebelum mendirikan Muhammadiyah, K.H. Ahmad Dahlan memulai aktivitas dakwah dan sosialisasi gagasan pembaruan melalui pendidikan. 1 Desember 1911, K.H. Ahmad Dahlan mendirikan Sekolah Dasar di Kauman Yogyakarta. Murid sekolah ini terdiri dari laki-laki dan perempuan. ${ }^{107}$ Selain itu, melalui koleganya di Budi Utomo, K.H. Ahmad Dahlan memberikan pelajaran agama ekstrakurikuler di Kweek School, Jetis, Yogyakarta dan OSVIA, Magelang. Pelajaran agama di kedua sekolah guebernemen tersebut diajarkan setiap Sabtu dan Minggu. Upaya ini dilakukan K.H. Ahmad Dahlan sebagai upaya membangun karakter yang integratif dan menghapuskan segregasi sosial-keagamaan: santri-abangan. ${ }^{108}$ kepribadian yang utuh: ulama yang intelek dan intelek yang ulama.

Tujuh tahun kemudian, 1918, Muhammadiyah mendirikan sekolah menengah yang diberi nama Madrasah Qismul Arqa'. Tahun 1920, lembaga pendidikan ini diubah menjadi Pondok Muhammadiyah sebelum akhirnya, tahun 1923, diubah menjadi Kweek School (sekolah guru) untuk memenuhi kebutuhan guru sekolah dasar. ${ }^{109} 1926$ Muhammadiyah mendirikan Taman 
Kanak-Kanak Bustanul Athfal. Pada tahun yang sama didirikan Hollandsh Inlandsche School (HIS) met de Qur'an-yang kemudian diganti menjadi HIS Muhammadiyah di Jakarta dan Kudus. Muhammadiyah kemudian membangun Meer Uitgebreid Lager Onderwijs (MULO), Hollandsch Inlandsche Kweekschool (HIK), Schakel School dan Algemeene Middelbare School (AMS). Komposisi pelajaran agama dalam kurikulum lembaga-lembaga pendidikan tersebut berkisar $10-15 \%$ pelajaran agama sisanya terdiri dari pelajaran umum. ${ }^{110}$

Relasi komplementer antara pendidikan dengan dakwah Muhammadiyah dapat dilihat dari korelasi positif antara pendirian sekolah dengan berdirinya cabang-cabang baru. Di pusat-pusat kota di Jawa, pembentukan cabangcabang Muhammadiyah hampir selalu bersamaan atau beriringan dengan berdirinya sekolah. ${ }^{111}$ Selain alasan-alasan yang bersifat teologis dan ideologis, dalam beberapa aspek, pengadopsian sistem pendidikan Barat ke dalam Muhammadiyah merupakan upaya "pragmatis" para pendiri organisasi ini agar mendapatkan dukungan masyarakat kota yang memang sudah welcome terhadap pendidikan-dan budaya-Barat sebagai captive market. Kedua, dalam praktik penyelenggaraannya kegiatan pendidikan menyatu dengan tabligh: pengajian agama kepada kelompok dewasa secara sistematis. Ketiga, pendidikan berorientasi untuk membentuk kader organisasi dan guru-buru agama. $^{112}$

Korelasi antara pendidikan dengan dakwah dan perkaderan nampak dari formulasi tujuan pendidikan Muhammadiyah. Kepada murid-muridnya, K.H. Ahmad Dahlan berpesan: "dadiyo mester, dokter lan insinyur, aja lali nyambut gawe kanggo Muhammadiyah. "113(Jadilah mester-sarjana hukum-, dokter dan insinyur, dan jangan pernah letih berjuang untuk Muhammadiyah). Pesan ini menggambarkan bagaimana fungsi pendidikan sebagai lembaga perkaderan. Sosok kader Muhammadiyah yang diharapkan dapat dilihat dari rumusan tujuan pendidikan Muhammadiyah. Mengutip dari Deliar Noer, MT. Arifin memaparkan tujuan kependidikan Muhammadiyah yang merupakan gagasan orisinal K.H. Ahmad Dahlan sebagai berikut:

1. Pendidikan moral, akhlak, yaitu sebagai usaha menanamkan karakter manusia yang baik berdasar al-Qur'an dan Sunnah.

2. Pendidikan individu, yaitu sebagai usaha untuk menumbuhkan kesadaran individu yang utuh, yang berkeseimbangan antara perkembangan mental dan jasmani, antara keyakinan dan intelek, antara perasaan dengan akal pikiran, serta antara dunia dengan akhirat. 
3. Pendidikan kemasyarakatan, yaitu sebagai usaha untuk menumbuhkan kesediaan dan keinginan hidup bermasyarakat. ${ }^{114}$

Secara fungsional, pendidikan Muhammadiyah juga berperan mempersatukan masyarakat yang majemuk (pluralistik) tidak hanya secara kultural tetapi juga keagamaan. Muhammadiyah menyelenggarakan pendidikan inklusif, education for all (pendidikan untuk semua) bagi siswa dari kalangan Muslim dan non-Muslim, santri dan abangan, laki-laki dan perempuan. Pendidikan bisa menjadi meeting point diantara para siswa yang berbeda-beda latar belakang agamanya. Pelajaran agama Islam yang diselenggarakan K.H. Ahmad Dahlan di Kweek Schoo/ terbuka untuk seluruh siswa: Muslim dan non-Muslim. Gambaran umum praktik pendidikan di sekolah tersebut dijelaskan K.H. Sudja' sebagai berikut:

K.H. Ahmad Dahlan tiap-tiap hari Minggu sejak pagi dikerumuni para siswa sekolah Kweek School yang diberi pelajaran agama Islam pada tiaptiap hari Sabtu sore, siswa-siswa mana bukan saja siswa yang terdiri dari anak-anak Islam, tetapi anak Kristen, anak Katolik, anak Theosofi dan lain-lain ideologi yang bukan Islam. Mereka memang anak yang cerdascerdas otaknya, tidak dapat menerima keterangan-keterangan yang belum atau tidak cocok dengan jalan akal pikirannya. Memang K.H. Ahmad Dahlan bermaksud yang demikian itu. Oleh karenanya pada tiap-tiap hari Minggu merupakan diskusi Agama dengan para siswa Kweek School di Yogyakarta. ${ }^{115}$

Dalam format yang sederhana, praktik pelajaran agama dialogis yang dilaksanakan K.H. Ahmad Dahlan merupakan bentuk sederhana pendidikan agama non-confessional dimana siswa non-Muslim secara sukarela mempelajari Islam sebagai wawasan pengetahuan.

Karena fungsinya sebagai lembaga dakwah, Muhammadiyah senantiasa bersikap kritis terhadap setiap kebijakan yang bertentangan atau menghambat aktivitas pendidikan. Pada zaman penjajahan Belanda, Muhammadiyah bersama para Muslim lainnya menentang keras pemberlakuan Goeroe Ordonnantie (Ordonansi Guru) ${ }^{116}$ karena sangat membatasi kebebasan beragama dan ruang gerak umat Islam untuk menyebarkan agamanya. ${ }^{117}$ Selain isinya yang sangat intrusive, Muhammadiyah menilai pemerintah kolonial Belanda tidak fair dan tidak konsisten dalam menjalankan Ordonansi Guru. Dalam praktiknya, pemerintah Belanda yang sekuler dan-seharusnya-netral 
agama memihak umat Kristiani dengan mengizinkan mereka mengajarkan agama Kristen di sekolah guebernemen setiap hari Jumat. Sebaliknya, pemerintah Belanda melarang Muhammadiyah memberikan pendidikan agama Islam ekstra kurikuler di OSVIA yang sudah dirintis sejak lama oleh K.H. Ahmad Dahlan. ${ }^{118}$

Melalui berbagai lobi Muhammadiyah menuntut agar Ordonansi Guru tersebut dicabut. Muhammadiyah juga menuntut agar pemerintah tidak melakukan subordinasi dan domestikasi pendidikan agama. Para pemimpin Muhammadiyah dan umat Islam di berbagai tempat, seperti di Minangkabau, meminta pemerintah Belanda memberikan mandat yang lebih luas dan otonomi untuk mengelola usaha pendidikan agama secara mandiri tanpa campur tangan pemerintah. ${ }^{119}$ Meskipun tuntutan ini tidak dikabulkan, pemerintah Belanda-akhirnya-mengakomodir aspirasi Muhammadiyah dengan memberikan konsesi berupa pembebasan para mubalig Muhammadiyah dari semua ketentuan di dalam Ordonansi Guru. ${ }^{120}$ Tindakan pemerintah yang sangat intrusive dan over sensitive terhadap kegiatan umat Islam nampaknya disebabkan oleh eskalasi perlawanan umat Islam kepada kolonialisme Belanda dan kekhawatiran meningkatnya kemajuan pendidikan Islam bisa menyaingi sekolah guebernemen sebagai agen Westernisasi dan pembentukan kelompok yang propemerintah. ${ }^{121}$

Strategi Muhammadiyah yang menempatkan pendidikan sebagai ujung tombak dakwah membuatnya sering bersinggungan dengan kepentingan kelompok lain, khususnya Kristen yang memilih pendidikan sebagai kegiatan sosial yang utama. Baik umat Kristen maupun Muhammadiyah menjadikan Muhammadiyah sebagai agen misionari agama. Faktor inilah yang membuat dinamika perjumpaan Muhammadiyah dan umat Islam pada umumnya dengan Kristen diwarnai ketegangan termasuk di dalamnya hal-hal yang terkait dengan pendidikan agama di sekolah swasta. ${ }^{122}$ Lembaga pendidikan menjadi "battle ground" politik identitas keagamaan.

Menurut Aritonang, polemik seputar pendidikan agama di sekolah pada era kemerdekaan mulai bergulir sejak tahun 1960-an, pada saat kalangan Islam mengeluhkan pemberian pendidikan Agama Kristen kepada siswa-siswa beragama lain di sekolah-sekolah Katolik dan Kristen ${ }^{123}$. Keluhan kalangan Islam dilatarbelakangi praktek penyelenggaraan pendidikan agama di sekolahsekolah berciri khusus Kristen dan Katolik yang tetap mengajarkan pendidikan agama Kristen pada siswa-siswinya yang beragama Islam. Padahal kebijakan pendidikan dalam UU No. 4 Tahun 1950 jo UU No. 20 Tahun 1954 jelas 
mengatur sekolah-sekolah swasta berciri khusus Kristen untuk memberikan pendidikan agama Islam pada siswa Muslim meskipun kebijakan ini belum bersifat mengikat. Kondisi demikian ini memicu ketegangan kalangan Islam dengan kelompok Kristen. GBHN Tahun 1966 merespons perkembangan tersebut dengan mengharuskan semua siswa dari pelbagai tingkatan pendidikan untuk dapat mengikuti pelajaran agama sesuai dengan agama yang dianutnya ${ }^{124}$.

Kontroversi penyelenggaraan pendidikan agama kembali mencuat pada saat perancangan UU 1989 oleh Departemen Pendidikan dan Kebudayaan. Kalangan Islam seperti Muhammadiyah dan MUI menilai sebagian isi rancangan undang-undangan mengabaikan eksistensi pendidikan agama ${ }^{125}$. Muhammadiyah menuntut agar setiap siswa berhak mendapatkan pendidikan agama sesuai keyakinannya dan diajarkan oleh guru yang seagama. Muhammadiyah melalui Lukman Harun, yang waktu menduduki kursi DPR, mengingatkan jika pemerintah tidak mengakomodasi tuntutan umat Islam maka akan terjadi instabilitas keamanan nasional ${ }^{126}$. Akhirnya melalui lobi Muhammadiyah dan MUI, Rancangan Undang-undang Sistem Pendidikan Nasional Tahun 1989 ditetapkan dan diberlakukan Maret 1989 dengan mengakui secara eksplisit peran pendidikan agama pada semua jenis, jalur, dan jenjang pendidikan. Lebih dari itu, landasan kokoh dari peraturan ini dijelaskan dalam penjelasan pasal 28 ayat $2 .^{127}$

Konsistensi sikap Muhammadiyah terhadap hak siswa untuk mendapatkan pendidikan agama sesuai agamanya terlihat kembali pada saat perdebatan RUUSPN No. 20 Tahun 2003 mencuat ke permukaan. Argumentasi yang diajukan kalangan pendukung dan penentang tidak jauh dari pembelaan serupa pada saat polemik RUUSPN 1989. Menurut Romo Widjojo, pada kasus sekolah-sekolah swasta berciri khusus agama adalah sangat sulit untuk menyediakan pendidikan agama yang berbeda dari orientasi agama sekolah. Atas dasar itu, sekolah-sekolah Katolik tidak memberikan pendidikan agama selain orientasi agama sekolah. Hal ini diperkuat pernyataan Dewan Bishop Indonesia yang tidak mengizinkan sekolah Katolik mengajarkan agama selain Katolik $^{128}$.

Namun Muhammadiyah mendesak pemerintah untuk mengesahkan RUU Sisdiknas tersebut. Dalam pandangan organisasi ini, substansi maupun berbagai aspek di dalam RUU Sistem Pendidikan Nasional (Sisdiknas) memenuhi persyaratan menjadi UU. UU Sisdiknas. ini berfungsi sebagai landasan konstitusional bagi penyelenggaraan sistem pendidikan di Indonesia dan 
pembentukan karakter serta peradaban bangsa. Terkait pasal 13 ayat 1 yang menjadi polemik, PP Muhammadiyah menilai sudah sejalan dengan prinsip Hak Asasi Manusia, demokrasi, pluralisme, konstitusi dasar negara, serta nilainilai moral universal dan agama. Sehingga peraturan demikian dijalankan akan maka akan mendorong pembentukan moral generasi penerus bangsa yang berbasis keyakinan keagamaan. Dampak lain yang adalah mengurangi kecenderungan perpindahan agama yang menjadi salah satu faktor konflik antar umat beragama dan mengganggu integritas bangsa. ${ }^{129}$

\section{KESIMPULAN}

Potret respons Muhammadiyah terhadap permasalahan pendidikan agama, khususnya di sekolah-sekolah berciri khusus agama, menyimpulkan konsistensi Muhammadiyah di dalam mengawal misi dan mempertahankan identitasnya sebagai gerakan Islam dan dakwah amar ma'ruf nahi munkar, peran dan tanggungjawab moral-politik organisasi ini dalam kancah pendidikan bangsa. Muhammadiyah berusaha dan-dalam beberapa hal-berhasil mengaksentuasikan pandangannya mengenai eksistensi pendidikan agama dalam koridor hukum dan perundangan negara.

Upaya Muhammadiyah memperjuangkan hak-hak pendidikan agama di lembaga pendidikan merupakan bagian dari strategi dakwah struktural: dakwah melalui saluran-saluran politik yang bersifat top-down. ${ }^{130}$ Aturan legal formal diperlukan oleh masyarakat untuk menjamin pluralisme keagamaan dalam masyarakat multirelijius. Lembaga pendidikan, bagi Muhammadiyah, tidak hanya memikul peran-peran keilmuan-sekuler namun juga harus memiliki dimensi transendental dalam bentuk penghargaan akan hak anak untuk dididik dalam habitat keagamaannya sendiri.

Pada banyak kasus, organisasi ini telah berhasil membangun lembaga pendidikannya sebagai potret empiris dari proses kohabitasi pendidikan agamaagama. Dalam perspektif Knitter, institusi pendidikan Muhammadiyah telah membuka jalan bagi terjadinya proses interaksi bahkan pertemuan (encounter) pandangan agama-agama yang merupakan bentuk praksis dari pluralisme agama. ${ }^{131}$

\section{CATATAN AKHIR}

1 Berdasarkan Sensus Penduduk tahun 2000, di Indonesia terdapat 101 etnis yang memiliki subetnis masing-masing. Total jumlah etnis dan subetnis lebih dari 1000. Komposisi etnis terbesar dengan jumlah lebih dari satu juta adalah Jawa 
(83.865.724), Sunda (30.978.404), Melayu (6.946.040), Madura (6.771.727), Batak (6.076.440), Minangkabau (5.475.145), Betawi (5.041.688), Bugis (5.010.421), Banten (4.113.162), Banjar (3.496.273), Bali (3.027.525), Sasak (2.611.059), Cirebon (1.890.102), Tionghoa (1.738.936). Lihat Leo Suryadinata, Evi Nurvidya Arifin dan Aris Ananta, Penduduk Indonesia: Etnis dan Agama dalam Era Perubahan Politik, (Jakarta: LP3ES, 2003), h. 6-7.

2 Menurut Sensus Penduduk tahun 2000, jumlah dan persentase pemeluk Agama adalah sebagai berikut: Islam $(177.528 .772=88,22 \%)$, Kristen (17.954.977=8,92\%), Hindu (3.651.939=1,81\%), Budha (1.694.682=0,84\%), lainnya $(411.629=0,20 \%)$. Pada Sensus Penduduk 2000, belum ada kategori khusus untuk Agama Konghucu, sehingga dimasukkan kategori Agama lainnya. Lihat Leo Suryadinata, Evi Nurvidya Arifin dan Aris Ananta, Penduduk Indonesia: Etnis dan Agama Dalam Era Perubahan Politik, (Jakarta: LP3ES, 2003), h. 102.

3 Riaz Hassan, Keragaman Iman: Studi Komparatif Masyarakat Muslim, terjemahan Jajang Jahroni, dkk (Jakarta: Raja Grafindo Persada-PPIM, 2006).

4 Abdullahi Ahmed An-Na'im, Islam dan Negara Sekuler: Menegosiasikan Masa Depan Syariah, terjemah Sri Murniati, (Bandung:Mizan, 2007), h. 47.

5 Dalam Muktamar di Semarang tahun 1984, Nahdlatul Ulama menerima Pancasila sebagai asas organisasi. Setahun kemudian, 1985, melalui Muktamar ke 41 yang diselenggarakan di Surakarta, Muhammadiyah menerima Pancasila sebagai asas organisasi dan mengubah tujuan organisasi yang semula "untuk mewujudkan masyarakat Islam" menjadi: "membentuk masyarakat utama, adil dan makmur yang diridai Allah SWT." Sebagaimana ditulis Lukman Harun dalam Muhammadiyah dan Azas Pancasila, (Jakarta:Pustaka Panjimas, 1989), penerimaan Muhammadiyah atas Pancasila memerlukan waktu yang sangat panjang dan perdebatan teologis yang berdampak pada keluarnya kelompok "puritan" dari Muhammadiyah. Pada Muktamar ke 44 di Jakarta, Muhammadiyah kembali memasukkan "Islam" sebagai asas organisasi. Meskipun demikian, sebagaimana disampaikan Ketua Umum PP. Muhammadiyah, M. Din Syamsuddin, dalam pidato iftitah sidang Tanwir Muhammadiyah, 25 April 2007, di Yogyakarta, Muhammadiyah tetap tegas mendukung Pancasila sebagai dasar negara.

6 Di dalam Undang-undang Dasar 1945 pasal 29 disebutkan: (1) Negara berdasarkan atas Ketuhanan Yang Maha Esa; (2) Negara menjamin kemerdekaan tiap-tiap penduduk untuk memeluk agamanya masing-masing dan untuk beribadat menurut agamanya dan kepercayaannya itu.

7 Azyumardi Azra, Konteks Berteologi di Indonesia: Pengalaman Islam, (Jakarta: Paramadina, 1999), h. 40.

8 Kajian menarik mengenai Islam dan budaya lokal dapat dibaca dari Simuh, Islam dan Pergumulan Budaya Jawa, (Jakarta: Teraju, 2003) dan Muhammad Zafar Iqbal, Kafilah Budaya: Pengaruh Persia Terhadap Kebudayaan Indonesia, (Jakarta: Citra, 2006). Dalam konteks Muhammadiyah, sikap terhadap budaya lokal merupakan wacana yang menarik. Perdebatan internal Muhammadiyah 
mengenai kebudayaan menunjukkan terjadinya pluralitas pemikiran yang dinamis sepanjang sejarah. Pluralitas pemikiran tersebut menyebabkan terjadinya perbedaan strategi dakwah dan gerakan persyarikatan antara kelompok "puritan" dengan kelompok "kultural" dan melahirkan beberapa varian dalam tubuh Muhammadiyah. Kajian komprehensif mengenai masalah ini dapat dibaca dari Abdul Munir Mulkhan, Islam Murni dalam Masyarakat Petani, (Yogyakarta: Yayasan Bentang Budaya, 2000) dan Asykuri Ibn Chamim, dkk., Purifikasi $\mathfrak{E}$ Reproduksi Budaya di Pantai Utara Jawa: Muhammadiyah dan Seni Lokal, (Surakarta: PSB-PS UMS, 2003).

9 Jamhari dan Jajang Jahroni (ed.), Gerakan Salafi Radikal di Indonesia, (Jakarta: Rajawali Press, 2004).

10 Angel Rabasa et.al., Building Moderate Muslim Networks (California: RAND Corporation, 2007), h. 66-68.

11 Vanessa Baird, "In the Name of God", New Internationalist, 370, h. 9-12. Mengutip dari berbagai sumber, Vanessa berkesimpulan bahwa mayoritas konflik keagamaan seperti di Gujarat (India), Palestina, Thailand dan Philipina disebabkan oleh faktor nonagama terutama politik. Konflik politik tersebut sarat dengan nuansa agama karena perbedaan agama di antara kelompokkelompok yang terlibat konflik.

12 Robert W. Hefner, "Muslim Democrats and Islamist Violence in Post Soeharto Indonesia” dalam Robert W. Hefner, Remaking Muslim Politics: Pluralism, Contestation, Democratization (Princeton: Princeton University Press, 2005), h. 273 301. Lihat juga Ahmad Suaedy dan Rumadi (Editor), Politisasi Agama dan Konflik Komunal: Beberapa Isu Penting di Indonesia, (Jakarta: The Wahid Institute, 2007).

13 Amartya Sen, Identity EF Violence: The Illusion of Destiny (New York: WW. Norton $\&$ Company, 2006).

14 Tri Ratnawati, "Mencari Kedamaian di Maluku: Suatu Pendekatan HistorisPolitis” dalam W.A.L. Stokhof dan Murni Jamal (Editor), Konflik Komunal di Indonesia Saat Ini, (Leiden-Jakarta: INIS-PBB, 2003), h. 3-14.

15 Frans Magnis Suseno, "Faktor-faktor yang Mendasari Konflik Antara Kelompok Etnis dan Agama di Indonesia: Pencegahan dan Pemecahan" dalam W.A.L. Stokhof dan Murni Jamal (Editor), Konflik Komunal di Indonesia Saat Ini, (LeidenJakarta: INIS-PBB, 2003), h. 121-125.

16 Mahatir Mohammad, Globalization and the New Realities (Selangor, Malaysia: Pelanduk Publication, 2002), h. 179.

17 Bassam Tibi, The Challenge of Fundamentalism: Political Islam and the New World Order (Barkeley, Los Angeles: University of California Press, 1998).

18 Charles Kimball, Kala Agama Jadi Bencana, terjemah Nurhadi (Bandung: Mizan, 2003), h. 65.

19 Richard Bonney, Jihad from Qur'an to bin Laden (New York: Palgrave Macmillan, 2004).

20 Kautsar Azhari Noer, "Pluralisme dan Pendidikan Agama di Indonesia: Menggugat Ketidakberdayaan Sistem Pendidikan Agama," dalam Th. Sumartana, 
dkk., Pluralisme, Konflik dan Pendidikan Agama di Indonesia, (Yogyakarta: Interfidei, 2001), h. 234-239.

21 Wahyu Pramudya, “Pluralitas Agama: Tantangan 'Baru' Bagi Pendidikan Keagamaan di Indonesia”, Veritas, 6/2 (Oktober 2005): h. 279-290.

22 Kuntowijoyo, "Konvergensi dan Politik Baru Islam” dalam Abdul Munir Mulkhan, Runtuhnya Mitos Politik Santri, (Yogyakarta: Sipress, cetakan ke 2, 1999), h. xi.

23 Pendapat ini antara lain dikemukakan olen Daoed Joesoef, menteri Pendidikan dan Kebudayaan Indonesia (1978-1983). Menurut Joesoef: “... pendidikan agama, agar efektif, sebaiknya diberikan di luar jalur pendidikan umum formal, berupa Zondagschool bagi agama Kristen dan Katolik. Bila mengenai agama Islam kiranya baik pula surau difungsikan sebagai tempat pengajian... dengan begitu penduduk juga didorong menjadi semakin erat hubungannya dengan surau yang ada di RT atau RW masing-masing.”. Daoed Joesoef, Dia dan Aku: Memoar Pencari Kebenaran, (Jakarta: Kompas, 2006), h. 814.

24 Denise Cush, "Should Religious Studies be Part of the Compulsory State School Curriculum?" British Journal of Religious Education, 29 (3), September 2007, h. 221-227.

25 M. Saerozi, Politik Pendidikan Agama dalam Era Pluralisme, (Yogyakarta: Tiara Wacana, 2004).

26 Pasal 3 Undang-undang 20/2003 tentang Sistem Pendidikan Nasional: "Pendidikan nasional.... bertujuan untuk berkembangnya potensi peserta didik agar menjadi manusia yang beriman dan bertakwa kepada Tuhan Yang Maha Esa, berakhlak mulia,...”.

27 Pasal 36 (3, a, b, h) Undang-undang 20/2003: "Kurikulum disusun sesuai dengan jenjang pendidikan... dengan memperhatikan: (a) peningkatan iman dan takwa; (b) peningkatan akhlak mulia;... (h) agama.”. Pasal 37 (1): “Kurikulum pendidikan dasar dan menengah wajib memuat: (a) pendidikan agama... (2) Kurikulum pendidikan tinggi wajib memuat: (a) pendidikan agama...”.

28 Undang-undang 20/2003, pasal 12 (1): "Setiap peserta didik pada setiap satuan pendidikan berhak: (a) mendapatkan pendidikan agama sesuai dengan agama yang dianutnya dan diajarkan oleh pendidik yang seagama."

29 Listia, dkk., Problematika Pendidikan Agama di Sekolah: Hasil Penelitian tentang Pendidikan Agama di Yogyakarta 2004-2006, (Yogyakarta: Interfidei, 2007).

30 Adian Husaini, Solusi Damai Islam-Kristen di Indonesia, (Jakarta: Pustaka Da’i, 2003).

31 Sampai tahun 2000, Muhammadiyah memiliki 3.979 Taman Kanak-kanak (TK); 6 Sekolah Luar Biasa (SLB); 940 Sekolah Dasar (SD); 1.332 Madrasah Ibtidaiyyah (MI)/Diniyyah (Madin); 2.143 Sekolah Menengah Pertama (SMP)/ Madrasah Tsanawiyah (MTs); 979 Sekolah Menengah Atas (SMA)/Madrasah Aliyah (MA); 101 Sekolah Menengah Kejuruan (SMK), 13 Muallimin/ Muallimat; 3 Sekolah Farmasi dan 65 Pondok Pesantren. Muhammadiyah memiliki 36 Universitas; 72 Sekolah Tinggi; 54 Akademi dan 4 Politeknik. Siswa dan mahasiswa di lembaga pendidikan Muhammadiyah berasal dari latar 
belakang agama yang berbeda-beda. Pimpinan Pusat Muhammadiyah, Berita Resmi Muhammadiyah: Edisi Khusus Tanfidz Keputusan Muktamar Muhammadiyah ke 45 di Malang, (Yogyakarta: Suara Muhammadiyah, Rajab 1426 H/September 2005) h. 43.

32 Musthafa Kamal Pasha dan Adaby Darban, Muhammadiyah Sebagai Gerakan Islam dalam Perspektif Historis dan Ideologis, (Yogyakarta: LPPI Universitas Muhammadiyah Yogyakarta, cetakan III, 2003), h. 121-126.

33 Surat Keputusan Majelis Pendidikan Dasar dan Menengah tentang Tanfidz Keputusan Rapat Kerja Nasional (Rakernas) Majelis Pendidikan Dasar dan Menengah (Dikdasmen) se-Indonesia.

34 M. Saerozi, Politik Pendidikan Agama dalam Era Pluralisme: Telaah Historis atas Kebijaksanaan Pendidikan Agama Konvensional di Indonesia, (Yogyakarta: Tiara Wacana, 2004).

35 Abdurrahman Assegaf, Politik Pendidikan Nasional: Pergeseran Kebijakan Pendidikan Agama Islam dari Praproklamasi ke Reformasi, (Yogyakarta: Kurnia Kalam, 2005).

36 Ruswan, Studi Komparasi Sikap Toleransi Beragama Mahasiswa Akademi Kebidanan dan Universitas Wahid Hasyim, (Semarang: Puslit IAIN Walisongo, 2003).

37 Jeny Elna Mahupale, Pendidikan Agama Berwawasan Multikultural: Analisis Hubungan dan Pandangan Agama terhadap Pandangan Sikap Perilaku Pluralis, Tesis, Universitas Gajah Mada, Yogyakarta, 2007.

38 Listia, dkk., Problematika Pendidikan Agama di Sekolah, (Yogyakarta: Interfidei, 2007).

39 Yayah Khisbiyah dan Atiqa Sabardila (ed), Pendidikan Apresiasi Seni: Wacana dan Praktik untuk Toleransi Pluralisme Budaya, (Surakarta: PSB-PS UMS, 2004).

40 Fuad Fachruddin, Agama dan Pendidikan Demokrasi: Pengalaman Muhammadiyah dan NU, (Jakarta: INSEP, 2006).

41 Badrus Soleh (ed), Budaya Damai Komunitas Pesantren, (Jakarta: LP3ES, LSAF, TAF; 2007).

42 Mitsuo Nakamura, The Crescent Arises Over the Banyan Tree: A Study of the Muhammadiyah Movement in A Central Java Town, (Cornell University: Unpublished Thesis, 1976).

43 Ahmad Najib Burhani, Muhammadiyah and Javanese Culture: Appreciation and Tension, (Leiden, Unpublished Thesis, 2004).

44 Achmad Jainuri, Ideologi Kaum Reformis: Melacak Pandangan Muhammadiyah Masa Awal, (Surabaya: LPAM, 2002). Lihat juga Achmad Jainuri, TheMuhammadiyah Movement in The Twentieth Century Indonesia: A Socio-Religious Study, (Montreal: Unpublished Thesis, 1992).

45 Alwi Shihab, Membendung Arus: Respons Gerakan Muhammadiyah terhadap Misi Kristen di Indonesia, (Bandung: Mizan, cetakan I, 1998).

46 Alfian, Muhammadiyah: The Political Behavior of a Muslim Modernist Organization Under Dutch Colonialism (Yogyakarta: Gadjahmada University Press, 1989).

47 MT. Arifin, Gagasan Pembaharuan Muhammadiyah Dalam Bidang Pendidikan (Jakarta: Pustaka Jaya, 1987).

48 Amir Hamzah Wirjosukarto, Pendidikan dan Pengadjaran Muhammadijah Dalam 
Masa Pembaharuan Semesta (Jogjakarta: Pembaharuan dan Pengadjaran Islam, 1962).

49 Majelis Tarjih dan Pengembangan Pemikiran Islam PP. Muhammadiyah, Tafsir Tematik Al-Qur'an tentang Hubungan Sosial Antar Umat Beragama (Yogyakarta: Pustaka SM, 2000).

50 Pradana Boy ZTF, In Defense of Pure Islam: The Conservative-Progressive Debate within Muhammadiyah, unpublished Masters Tesis, Faculty of Asian Studies, Australian National University, 2007.

51 Biyanto, Pluralisme Keagamaan dalam Perspektif Kaum Muda Muhammadiyah, Disertasi, tidak diterbitkan, Program Pascasarjana, Institut Agama Islam Negeri (IAIN) Sunan Ampel, Surabaya, 2008.

52 Abdul Munir Mulkhan, Islam Murni dalam Masyarakat Petani, (Yogyakarta: Bentang, 2000).

53 Haedar Nashir, Meneguhkan Ideologi Gerakan Muhammadiyah, (Yogyakarta: Suara Muhammadiyah, 2006), h. vi.

54 Haedar Nashir, "Kembali ke Ideologi Muhammadiyah" dalam Hamdan Hambali, Ideologi dan Strategi Muhammadiyah, (Yogyakarta: Suara Muhammadiyah, 2006), h. x.

$55 \mathrm{MKCH}$, Matan 4.

56 Mukadimah Anggaran Dasar: "Hidup bermasyarakat itu adalah sunah (hukum qudrat-iradat) Allah atas kehidupan manusia di dunia ini.” Kepribadian Muhammadiyah: “... Muhammadiyah mendasarkan segala gerak dan amal usahanya atas prinsip-prinsip yang tersimpul dalam Mukadimah Anggaran Dasar, yaitu: a. Hidup manusia harus berdasar tauhid, ibadah dan taat kepada Allah; b. Hidup manusia bermasyarakat...".

57 Hamdan Hambali, Ideologi dan Strategi Muhammadiyah, (Yogyakarta: Suara Muhammadiyah, 2006), h. 17.

58 Pimpinan Pusat Muhammadiyah, Pedoman Hidup Islami Warga Muhammadiyah, (Yogyakarta: Suara Muhammadiyah, 2001), h. 66.

59 Dalam konteks ini PHI mengutip sebuah Hadits yang diriwayatkan oleh Abu Dawud dan Tirmidzi dari Ibn 'Amr: "Bahwasanya Abdullah Ibn 'Amr; disembelihkan untuknya seekor domba oleh keluarganya. Ketika ia tiba, ia berkata: 'Apakah engkau telah memberi (daging domba) kepada tetangga kita yang beragama Yahudi? Saya telah mendengar Rasulullah Saw bersabda:'Jibril senantiasa berpesan kepadaku untuk berbuat baik kepada tetangga, sehingga saya menyangka kemungkinan ia mendapat bagian hak harta waris. "

60 Pimpinan Pusat Muhammadiyah, Pedoman Hidup Islami....h. 67.

61 K.H. Mas Mansur, 12 Langkah Tafsir Muhammadiyah dalam Amir Hamzah Wirjosukarto (penyunting), Kiyahi Haji Mas Mansur: Pemikiran Tentang Islam dan Muhammadiyah, (Yogyakarta: YP2LPM-Hanindita, 1986), h. 196.

62 Amien Rais, Tauhid Sosial: Formula Menggempur Kesenjangan Sosial, (Bandung: Mizan, 1998), h. 10.

63 Qs. 1, al-Fatihah: 2: "Segala puji bagi Allah Tuhan semesta Alam".

64 Qs. 2, al-Baqarah: 185: "Bulan Ramadhan adalah bulan yang di dalamnya 
diturunkan (permulaan al-Qur'an, sebagai petunjuk bagi seluruh umat manusia...".

65 Qs. 7, al-Araf: 56: "Dan janganlah kamu membuat kerusakan di muka bumi sesudah (Allah) memperbaikinya..."

66 Qs. 49, al-Hujurat: 13: "Hai manusia, sesungguhnya Kami menciptakan kamu dari seorang laki-laki dan seorang perempuan dan menjadikan kamu berbangsabangsa dan bersuku-suku supaya kamu saling mengenal. Sesungguhnya orang yang paling mulia di antara kamu di sisi Allah adalah orang yang paling bertakwa...."

67 Qs. 28, al-Qashash: 77: "Dan carilah pada apa yang telah dianugerahkan oleh Allah kepadamu berupa kebahagiaan negeri akhirat dan janganlah kamu melupakan bagianmu dari kenikmatan duniawi. Berbuatlah baiklah kepada orang lain sebagaimana Allah telah berbuat baik kepadamu dan janganlah kamu berbuat kerusakan di muka bumi...”.

68 KRH. Hadjid, Pelajaran KHA. Dahlan.... h. 13.

69 KRH. Hadjid, Pelajaran KHA. Dahlan.... h. 14-15.

70 KRH. Hadjid, Pelajaran KHA. Dahlan.... h. 14.

71 KRH. Hadjid, Pelajaran KHA. Dahlan.... h. 14-15.

72 Hamdan Hambali, Ideologi dan Strategi.... h. 17.

73 K.H. Mas Mansur, 12 Langkah Muhammadiyah, dalam Amir Hamzah Wirjosukarto, KH. Mas Mansur: Pemikiran....h. 200.

74 Mukti Ali, "The Muhammadiyah Movement: A Bibliographical Introduction," M.A. Thesis (tidak dipublikasikan), Institute of Islamic Studies, McGill University, Montreal, 1957, h. 38-39.

75 K.H. Suja', Muhammadiyah dan Pendirinya, (Yogyakarta: Majelis Pustaka PP. Muhammadiyah, 1989), h. 3.

76 Ahmad Zaini Dahlan adalah seorang mufti Mazhab Syafi'i yang sangat berpengaruh dan dominan di Kota Mekah antara tahun 1870 sampai wafatnya 1886. Ahmad Zaini Dahlan sangat popular di kalangan orang-orang Jawa yang menunaikan ibadah haji. Keterangan lebih lengkap dapat dibaca Nico Kaptein, The Muhimmat al-Nafais: a Bilingual Meccan Fatwa Collection for Indonesian Muslims from the End of the Nineteenth Century, (Jakarta: INIS, 1997), h. 3-6.

77 Ahmad Najib Burhani, "The Muhammadiyah's Attitude to Javanese Culture in 1912-1930: Appreciation and Tension”, M.A. Thesis, (tidak dipublikasikan), Universiteit Leiden, The Netherland, 2004, h. 17.

78 Majelis Tarjih Muhammadiyah, Himpunan Putusan Majelis Tarjih.... h. 278.

79 K.H. Mas Mansur, 12 Langkah Muhammadiyah, dalam Amir Hamzah Wirjosukarto, KH. Mas Mansur: Pemikiran....h. 200.

80 Harun Nasution, Pembaharuan dalam Islam: Sejarah Pemikiran dan Gerakan, (Jakarta: Bulan Bintang, cetakan ke 13, 2003), h. 5.

81 PP. Muhammadiyah, Himpunan Keputusan Majelis Tarjih.... h. 281, 313.

82 Salam adalah transaksi bisnis di mana pembeli tidak melihat wujud fisik barang yang dijual karena penjual hanya menyebut ciri-ciri atau spesifikasi.

83 Achmad Jainuri, Ideologi Kaum Reformis: Melacak Pandangan Muhammadiyah 
Periode Awal, (Surabaya: LPAM, 2002), h. 117. tion Under Dutch Colonialism, (Yogyakarta: Gadjahmada University Press, 1989), h. 159-160.

96 Junus Salam, Riwajat Hidup K.H.A. Dalan.... h. 20.

97 MT. Arifin, Gagasan Pembaharuan.... h. 150.

98 PP. Muhammadiyah Majelis Tarjih, Himpunan Putusan Tarjih.... h. 276.

99 K.H. Mas Mansur, 12 Langkah Muhammadiyah, dalam Amir Hamzah Wirjosukarto, KH. Mas Mansur: Pemikiran.... h. 201.

100 K.H. Sudja' Muhammadiyah dan Pendirinya,.... h. 33.

101 Alfian, Muhammadiyah... h. 208.

102 H. Fachroedin adalah sekretaris Muhammadiyah pada masa K.H. Ahmad Dahlan. Selama hayatnya, Fachroedin aktif mengikuti beberapa organisasi Budi Utomo, Sarikat Islam dan Prinsen Bond (Persatuan Priyayi) dan ISDV (Organisasi Sosialis Indonesia). Karena tidak cocok dengan perilaku para anggotanya yang "borjuis", Fachroedin keluar dari Budi Utomo dan Prinsen Bond. Dia kemudian lebih banyak aktif di Sarikat Islam dan ISDV. Bagi dia, usaha kaum Kristen adalah dua sisi dari satu mata uang dengan kolonialisme Belanda. Sikap nasionalisme dan pembelaan Islam inilah yang dalam banyak aspek membuat Fachroedin sangat anti kepada setiap usaha Kristenisasi. Lihat Djarnawi Hadikusumo, Matahari-Matahari Muhammadiyah, (Yogyakarta: Percetakan Persatuan, t.th), h. 16-30.

103 Alfian, Muhammadiyah.... h. 209. lihat juga Alwi Shihab, Membendung Arus: Respons Gerakan Muhammadiyah terhadap Penetrasi Misi Kristen di Indonesia, (Bandung: Mizan, cetakah 1, 1998), h. 162. 
104 Abdul Munir Mulkhan, Islam Murni....H. 44.

105 Abdul Munir Mulkhan, Islam Murni.... h. 355.

106 Majelis Dikdasmen PP. Muhammadiyah, Hasil-hasil Rakernas Majelis Dikdasmen, Jakarta 2006.

107 Karel A. Steenbrink, Pesantren Madrasah Sekolah: Pendidikan Islam dalam Kurun Modern, (Jakarta: LP3ES, cetakan ke 2, 1994) h. 52.

108 MT. Arifin, Gagasan Pembaruan Muhammadiyah... h. 212.

109 MT. Arifin, Gagasan Pembaharuan Muhammadiyah... h. 219.

110 MT. Arifin, Gagasan Pembaharuan Muhammadiyah... h. 217-218.

111 Karel A. Steenbrink, Pesantren Madrasah Sekolah.... h. 57.

112 Karel A. Steenbrink, Pesantren Madrasah Sekolah.... h. 56.

113 Junus Salam, Riwajat Hidup K,H.A. Dahlan.... h. 63.

114 MT. Arifin, Gagasan Pembaharuan Muhammadiyah... h. 206.

115 K.H. Sudja', Muhammadiyah dan Pendirinya... h. 16.

116 Goeroe Ordonnantie (Ordonansi Guru) pertama kali dikeluarkan tahun 1905. Setelah banyak diprotes terutama oleh kalangan Muslim, Ordonansi tersebut diamandemen pada tahun 1925. Perubahan tersebut tetap saja tidak memuaskan karena tidak perubahan isi yang substantif. Tidak ada perubahan yang substantif. Isi Ordonansi yang sangat merugikan kegiatan Islam antara lain guru agama dan mubalig harus mendapatkan rekomendasi, menyampaikan isi pelajaran, dan memberikan kewenangan kepada pemerintah untuk memeriksa catatan pelajaran agama. Pemerintah Belanda berhak mencabut izin menjadi guru dan mubalig apabila tidak mematuhi ketentuan Ordonansi. Lihat Aqib Suminto, Politik Islam Hindia Belanda, (Jakarta: LP3ES, cetakan 3, 1996), h. 54.

117 Achmad Jainuri, Ideologi Kaum Reformis.... h. 202.

118 Ali Shihab, Membendung Arus... h. 164.

119 Hamka, Ayahku: Riwayat Hidup DR. Abdul Karim Amrullah dan Perjuangan Kaum Agama di Sumatera, (Jakarta: Umminda, 1982), h. 166-167.

120 Achmad Jainuri, Ideologi Kaum Reformis.... h. 203-204.

121 Maksum, Madrasah: Sejarah dan Perkembangannya, (Jakarta: Logos, 1999), h. 114.

122 Jan S. Aritonang, Sejarah Perjumpaan Kristen dan Islam di Indonesia, (Jakarta: BPK Gunung Mulia, cetakan ke 3, 2006).

123 Jan Aritonang, Sejarah Perjumpaan .... h. 588.

124 M. Sairozi, Politik Pendidikan Agama dalam Era Pluralisme: Telaah Historis atas Kebijaksanaan Pendidikan Agama Konvensional di Indonesia, (Yogyakarta: Tiara Wacana, 2004), h. 146.

125 M. Sairozi, Politik Pendidikan Agama.... h. 147.

126 Alwi Shihab, Membendung Arus .... h. 164.

127 M. Sairozi, Politik Pendidikan Agama..... h. 147.

128 Fatimah Husein, Muslim-Christian Relation in the New Order Indonesia: The Exclusivist and the Inclusivist Muslims Perspectives (Bandung: Mizan, 2005) h. 124.

129 Muhammadiyah: RUU Sisdiknas Sudah Sesuai, Hidayatullah.com. 07 Mei 2003. 
130 Kuntowijoyo, Muslim Tanpa Masjid.... h. 118.

131 Lih. Paul F. Knitter, Pengantar Teologi Agama-Agama (terjemahan) (Yogyakarta: Kanisius, 2008).

\section{DAFTAR PUSTAKA}

Suryadinata,Leo. Nurvidya Arifin, Evi dan Ananta,Aris. 2003. Penduduk Indonesia: Etnis dan Agama dalam Era Perubahan Politik. Jakarta: LP3ES.

Hassan,Riaz. 2006. Keragaman Iman: Studi Komparatif Masyarakat Muslim, terjemahan Jajang Jahroni, dkk. Jakarta: Raja Grafindo Persada-PPIM.

An-Na'im,Abdullahi Ahmed. 2007. Islam dan Negara Sekuler: Menegosiasikan Masa Depan Syariah, terjemah Sri Murniati. Bandung:Mizan.

Harun, Lukman. 1989. Muhammadiyah dan Azas Pancasila. Jakarta: Pustaka Panjimas.

Azra, Azyumardi. 1999. Konteks Berteologi di Indonesia: Pengalaman Islam. Jakarta: Paramadina.

Simuh. 2003. Islam dan Pergumulan Budaya Jawa. Jakarta: Teraju.

Iqbal,Muhammad Zafar. 2006. Kafilah Budaya: Pengaruh Persia Terhadap Kebudayaan Indonesia. Jakarta: Citra.

Mulkhan,Abdul Munir. 2000. Islam Murni dalam Masyarakat Petani. Yogyakarta: Yayasan Bentang Budaya.

Chamim,Asykuri Ibn. 2003. Purifikasi Eु Reproduksi Budaya di Pantai Utara Jawa: Muhammadiyah dan Seni Lokal. Surakarta: PSB-PS UMS.

Jamhari dan Jahroni, Jajang (ed.). 2004. Gerakan Salafi Radikal di Indonesia. Jakarta: Rajawali Press.

Rabasa, Angel et.al. 2007. Building Moderate Muslim Networks. California: RAND Corporation.

Hefner,Robert W. 2005. "Muslim Democrats and Islamist Violence in Post Soeharto Indonesia” dalam Robert W. Hefner, Remaking Muslim Politics: Pluralism, Contestation, Democratization. Princeton: Princeton University Press. h. 273-301.

Suaedy, Ahmad dan Rumadi (Editor). 2007. Politisasi Agama dan Konflik Komunal: Beberapa Isu Penting di Indonesia. Jakarta: The Wahid Institute.

Sen,Amartya. 2006. Identity $\mathcal{E}$ Violence: The Illusion of Destiny. New York: WW. Norton \& Company.

Ratnawati, Tri. 2003. "Mencari Kedamaian di Maluku: Suatu Pendekatan HistorisPolitis” dalam W.A.L. Stokhof dan Murni Jamal (Editor), Konflik Komunal di Indonesia Saat Ini. Leiden-Jakarta: INIS-PBB.h. 3-14.

Suseno, Frans Magnis. 2003. "Faktor-faktor yang Mendasari Konflik Antara Kelompok Etnis dan Agama di Indonesia: Pencegahan dan Pemecahan” dalam W.A.L. Stokhof dan Murni Jamal (Editor), Konflik Komunal di Indonesia Saat Ini. Leiden-Jakarta: INIS-PBB.

Mohammad, Mahatir. 2002.Globalization and the New Realities. Selangor, Malaysia: Pelanduk Publication.

Tibi, Bassam. 1998.The Challenge of Fundamentalism: Political Islam and the New World Order. Barkeley, Los Angeles: University of California Press. 
Kimball, Charles. 2003.Kala Agama Jadi Bencana, terjemah Nurhadi. Bandung: Mizan.

Bonney, Richard. 2004.Jihad from Qur'an to bin Laden. New York: Palgrave Macmillan. Noer, Kautsar Azhari. 2001. "Pluralisme dan Pendidikan Agama di Indonesia: Menggugat Ketidakberdayaan Sistem Pendidikan Agama," dalam Th. Sumartana, dkk., Pluralisme, Konflik dan Pendidikan Agama di Indonesia. Yogyakarta: Interfidei. h. 234-239.

Pramudya, Wahyu. 2005. “Pluralitas Agama: Tantangan 'Baru’ Bagi Pendidikan Keagamaan di Indonesia”, Veritas, 6/2, Oktober. h. 279-290.

Kuntowijoyo. 1999. "Konvergensi dan Politik Baru Islam" dalam Abdul Munir Mulkhan, Runtuhnya Mitos Politik Santri. Yogyakarta: Sipress, cetakan ke 2.

Joesoef, Daoed. 2006.Dia dan Aku: Memoar Pencari Kebenaran. Jakarta: Kompas.h. 814.

Cush, Denise. 2007. "Should Religious Studies be Part of the Compulsory State School Curriculum?" British Journal of Religious Education, 29 (3), September. h. 221-227.

M. Saerozi. 2004.Politik Pendidikan Agama dalam Era Pluralisme. Yogyakarta: Tiara Wacana.

Listia, dkk. 2007. Problematika Pendidikan Agama di Sekolah: Hasil Penelitian tentang Pendidikan Agama di Yogyakarta 2004-2006. Yogyakarta: Interfidei.

Husaini, Adian. 2003. Solusi Damai Islam-Kristen di Indonesia.Jakarta: Pustaka Da'i. Pimpinan Pusat Muhammadiyah. 2005.Berita Resmi Muhammadiyah: Edisi Khusus Tanfidz Keputusan Muktamar Muhammadiyah ke 45 di Malang. Yogyakarta: Suara Muhammadiyah, Rajab 1426 H/September.h. 43.

Pasha, Musthafa Kamal dan Adaby, Darban. 2003.Muhammadiyah Sebagai Gerakan Islam dalam Perspektif Historis dan Ideologis. Yogyakarta: LPPI Universitas Muhammadiyah Yogyakarta, cetakan III.

Assegaf, Abdurrahman. 2005.Politik Pendidikan Nasional: Pergeseran Kebijakan Pendidikan Agama Islam dari Praproklamasi ke Reformasi. Yogyakarta: Kurnia Kalam.

Ruswan. 2003.Studi Komparasi Sikap Toleransi Beragama Mahasiswa Akademi Kebidanan dan Universitas Wahid Hasyim. Semarang: Puslit IAIN Walisongo.

Mahupale, Jeny Elna. 2005. Pendidikan Agama Berwawasan Multikultural: Analisis Hubungan dan Pandangan Agama terhadap Pandangan Sikap Perilaku Pluralis. Tesis. Yogyakarta: Universitas Gajah Mada.

Khisbiyah, Yayah dan Sabardila, Atiqa (ed). 2004.Pendidikan Apresiasi Seni: Wacana dan Praktik untuk Toleransi Pluralisme Budaya. Surakarta: PSB-PS UMS.

Fachruddin, Fuad. 2006. Agama dan Pendidikan Demokrasi: Pengalaman Muhammadiyah dan NU. Jakarta: INSEP.

Soleh, Badrus (ed). 2007. Budaya Damai Komunitas Pesantren. Jakarta: LP3ES, LSAF, TAF.

Nakamura, Mitsuo. 1976.The Crescent Arises Over the Banyan Tree: A Study of the Muhammadiyah Movement in A Central Java Town. Cornell University: Unpublished Thesis.

Burhani, Ahmad Najib. 2004.Muhammadiyah and Javanese Culture: Appreciation 
and Tension. Leiden: Unpublished Thesis.

Jainuri, Achmad. 2002.Ideologi Kaum Reformis: Melacak Pandangan Muhammadiyah Masa Awal. Surabaya: LPAM.

Jainuri, Achmad. 1992. TheMuhammadiyah Movement in The Twentieth Century Indonesia: A Socio-Religious Study. Montreal: Unpublished Thesis.

Shihab, Alwi. 1998.Membendung Arus: Respons Gerakan Muhammadiyah terhadap Misi Kristen di Indonesia. Bandung: Mizan, cetakan I.

Alfian. 1989. Muhammadiyah: The Political Behavior of a Muslim Modernist Organization Under Dutch Colonialism. Yogyakarta: Gadjahmada University Press.

MT. Arifin. 1987. Gagasan Pembaharuan Muhammadiyah Dalam Bidang Pendidikan Jakarta: Pustaka Jaya.

Wirjosukarto, Amir Hamzah. 1962.Pendidikan dan Pengadjaran Muhammadijah Dalam Masa Pembaharuan Semesta. Jogjakarta: Pembaharuan dan Pengadjaran Islam.

Majelis Tarjih dan Pengembangan Pemikiran Islam PP Muhammadiyah. 2000.Tafsir Tematik Al-Qur'an tentang Hubungan Sosial Antar Umat Beragama. Yogyakarta: Pustaka SM.

Boy, Pradana ZTF. 2007.In Defense of Pure Islam: The Conservative-Progressive Debate within Muhammadiyah. Asutralia:Faculty of Asian Studies, Australian National University. unpublished Masters Tesis.

Biyanto. 2008. Pluralisme Keagamaan dalam Perspektif Kaum Muda Muhammadiyah, Disertasi, Surabaya: Program Pascasarjana, Institut Agama Islam Negeri (IAIN) Sunan Ampel. tidak diterbitkan.

Mulkhan, Abdul Munir. 2000.Islam Murni dalam Masyarakat Petani. Yogyakarta: Bentang.

Nashir, Haedar. 2006.Meneguhkan Ideologi Gerakan Muhammadiyah. Yogyakarta: Suara Muhammadiyah.

Nashir, Haedar. 2006. "Kembali ke Ideologi Muhammadiyah" dalam Hamdan Hambali, Ideologi dan Strategi Muhammadiyah,. Yogyakarta: Suara Muhammadiyah.

Hambali, Hamdan. 2006.Ideologi dan Strategi Muhammadiyah. Yogyakarta: Suara Muhammadiyah.

Pimpinan Pusat Muhammadiyah. 2001.Pedoman Hidup Islami Warga Muhammadiyah. Yogyakarta: Suara Muhammadiyah.

Wirjosukarto, Amir Hamzah (penyunting). 1986.Kiyahi Haji Mas Mansur: Pemikiran Tentang Islam dan Muhammadiyah. Yogyakarta: YP2LPM-Hanindita.

Rais, Amien. 1998.Tauhid Sosial: Formula Menggempur Kesenjangan Sosial. Bandung: Mizan.

Ali, Mukti. 1957. "The Muhammadiyah Movement: A Bibliographical Introduction,” M.A. Thesis. Montreal: Institute of Islamic Studies, McGill University.h. 38-39.tidak dipublikasikan.

K.H. Suja'. 1989.Muhammadiyah dan Pendirinya. Yogyakarta: Majelis Pustaka PP Muhammadiyah.

Kaptein, Nico. 1997. The Muhimmat al-Nafais: a Bilingual Meccan Fatwa Collection for 
Indonesian Muslims from the End of the Nineteenth Century. Jakarta: INIS.

Burhani, Ahmad Najib. 2004. “The Muhammadiyah's Attitude to Javanese Culture in 1912-1930: Appreciation and Tension”, M.A. Thesis, The Netherland: Universiteit Leiden.

Nasution, Harun. 2003.Pembaharuan dalam Islam: Sejarah Pemikiran dan Gerakan. Jakarta: Bulan Bintang, cetakan ke 13.

Suminto, Aqib. 1996. Politik Islam Hindia Belanda. Jakarta: LP3ES, cetakan 3.

Hamka. 1982. Ayahku: Riwayat Hidup DR. Abdul Karim Amrullah dan Perjuangan Kaum Agama di Sumatera. Jakarta: Umminda.

Maksum. 1999.Madrasah: Sejarah dan Perkembangannya. Jakarta: Logos.

Aritonang, Jan S. 2006.Sejarah Perjumpaan Kristen dan Islam di Indonesia. Jakarta: BPK Gunung Mulia, cetakan ke 3. 